\title{
UČINKOVITOST NEKONVENCIONALNIH MJERA MONETARNE POLITIKE EUROPSKE SREDIŠNJE BANKE U POTICANJU FINANCIJSKOG I REALNOG DIJELA GOSPODARSTVA
}

\author{
EFFICIENCY OF UNCONVENTIONAL MONETARY \\ POLICY MEASURES OF THE EUROPEAN CENTRAL \\ BANK IN SUPPORTING THE FINANCIAL AND REAL \\ PART OF THE ECONOMY
}

SAŽETAK: Istraživanje ispituje učinkovitost nekonvencionalnih mjera monetarne politike Europske središnje banke, u periodu 2008m1 do 2017m12, služeći se Bayesovim strukturnim vektorskim autoregresijskim modelom (BSVAR) uz primjenu restrikcija nula i predznaka na funkcije odziva. Provedene nekonvencionalne mjere ostvarile su makroekonomski utjecaj, pokrenule oporavak realnih i financijskih varijabli. Najsnažniji odraz vidljiv je na izvozu, slijedi utjecaj na kreditnu aktivnost, potom nezaposlenost, industrijsku proizvodnju i obvezničke prinose, a najslabiji je na burzovnoj aktivnosti. Tendencije promjene industrijske proizvodnje i nezaposlenosti prate periode intenzivne promjene aktive ESB-a. Najveći utjecaj imao je kanal bankovnog kreditiranja, nakon kojega odmah potom po važnosti slijedi kanal cijena imovine (dionica). Treći po važnosti je kanal izvoza te na kraju kanal uravnoteženja portfelja.

KLJUČNE RIJEČI: nekonvencionalna monetarna politika, Europska središnja banka, Bayesov strukturni vektorski autoregresijski model, učinkovitost, kanali transmisije.

ABSTRACT: The study examines the effectiveness of unconventional monetary policy measures of the European Central Bank, in the period 2008m1 to 2017m12, using the Bayesian Structural Vector Autoregression Model (BSVAR) by incorporating zero and sign restrictions on response functions. Implemented unconventional measures have had a macroeconomic impact, triggering the recovery of real and financial variables. The strongest

Mr. sc. Boris Franović, Zagrebačka banka d.d., e-mail: Boris.Franovic@unicreditgroup.zaba.hr Ovim radom iznesene informacije isključiva su stajališta autora i ni kom slučaju ne predstavljaju stajališta Zagrebačke banke d.d. 
reflection is visible on exports, followed by the impact on credit activity, unemployment, industrial production, bond yields and the weakest on stock market activity. Trends in industrial production and unemployment follow periods of intense change in ECB assets. The biggest influence was had by the bank lending channel, which was immediately followed by the asset (equity) price channel. The third most important is the export channel and finally the portfolio balancing channel.

KEY WORDS: unconventional monetary policy, European Central Bank, Bayesian structural vector autoregression model, efficiency, transmission channels.

\section{UVOD}

Američka kriza na tržištu hipotekarnih zajmova u rujnu 2008. godine pretvorila se u globalnu financijsku krizu zahvativši i europodručje. Osim prvotne financijske zaraze, u jesen 2008. godine, europodručje je snažno pogodila prateća globalna recesija poznata kao „Velika“ jer je bila okidač rasplamsavanju tinjajućih političkih sukoba koji proizlaze iz heterogenosti monetarne unije. Tako se nakon prvotnih paničnih spašavanja posrnulih banaka u većini svojih članica, europodručje našlo u vrtlogu krize javnog duga niza država (Grčka, Portugal, Irska, Cipar, Španjolska, Italija), što je dovelo do eskalacije unutarnjeg dužničko-vjerovničkog spora, naročito između Grčke i Njemačke. Osim fiskalnog spora, europodručje je ugrozio i spor oko monetarne politike. Njemačkoj, kao vodećoj ekonomskoj sili, odgovarao je snažniji euro jer je većinu robe plasirala na unutarnja tržišta monetarne unije, dok su „periferne“ zemlje inzistirale na slabljenju eura i manjem inzistiranju na fiskalnoj disciplini. Izvozom dosta orijentirane na prekomorska tržišta bile su pogođene posljedicama američke i britanske nekonvencionalne monetarne politike koja je osjetno oslabila dolar i funtu sterling učinivši im izvoz trgovinski konkurentnijim. Te svojevrsne monetarno-fiskalne škare između nepopustljive i izvozno dominantne Njemačke s jedne i osjetno devalviranih dolara i funte izazvale su veliki unutarnji rascjep koji je prijetio čak i urušavanjem projekta monetarne unije.

U odnosu na američki Sustav saveznih rezervi (FED) i središnju banku Ujedinjenog Kraljevstva (BoE), Europska središnja banka (ESB) reagirala je sa zadrškom na već zahuktalu Veliku recesiju. Prvotno je provela programe pomoći: ${ }^{1}$ 1. Program tržišta vrijednosnih papira (engl. Securities Markets Programme (SMP)), 2. Program kupnje pokrivenih obveznica (Covered bond purchase programme (CBPP)) i 3. Program kupnje pokrivenih obveznica 2 (Covered bond purchase programme 2 (CBPP2)). Nakon njih ESB uspostavlja Programe kupnje imovine (eng. Asset purchase programmes (APP)) te paralelno provodi fazu reinvestiranja programa kupnje imovine koja traje do konca 2018. godine. U njoj ESB nastavlja reinvestirati isplate glavnice iz dospjelih vrijednosnih papira kupljenih u okviru programa kupnje imovine (APP). APP program sastojao se od: 1. Programa kupnje korporativnog sektora (engl. Corporate sector purchase programme (CSPP)), 2. Programa kupnje javnog sektora (engl. Public sector purchase programme (PSPP)), 3. Programa kupnje vrijednosnih papira (engl. Asset-backed securities purchase programme (ABSPP)) i 4. Pro-

ECB [online]. Dostupno na: https://www.ecb.europa.eu/mopo/implement/omt/html/index.en.html [23. veljače 2020.] 
grama kupnje pokrivenih obveznica 3 (CBPP3). Paralelno s programima kupnje imovine i reinvestiranjem dospjele imovine, ESB je provodio od sredine 2014. godine politiku negativne kamatne stope na sve depozite kojima iznos prelazi zahtijevani minimum, ali i na sve druge koje banke drže pri Eurosustavu.

U radu se postavljaju pitanja: 1. Koliko su i na koji način nekonvencionalne mjere ESB-a bile uspješne u poticanju financijskog dijela gospodarstva?; 2. Koliko su i na koji način nekonvencionalne mjere ESB-a bile učinkovite u poticanju realnog dijela gospodarstva?; 3) Putem kojih se kanala odvila transmisija poticaja nekonvencionalnih mjera na gospodarstva europodručja?

Rad se sastoji od pet dijelova. Nakon uvodnog, u drugom dijelu daje se kratki pregled dosadašnjih istraživanja, potom se u trećem izlaže metodologija koja se primjenjuje $u$ istraživanju. Četvrti dio iznosi prikaz i raspravu rezultata istraživanja. Peti dio sadrži zaključna razmatranja, ograničenja istraživanja i preporuke za buduća istraživanja.

\section{PREGLED DOSADAŠNJIH ISTRAŽIVANJA}

Rezultati dosad provedenih relevantnih istraživanja većinom nalaze da su nekonvencionalne mjere ESB-a imale utjecaj na gospodarstva europodručja. U nekim radovima, iako bilježe utjecaj, karakteriziraju ga pomalo nejasnim, a posebice u usporedbi s utjecajem koje su polučile mjere američkih Saveznih rezervi. Ipak, velika većina istraživanja nalazi značajnost utjecaja na realni i financijski dio gospodarstva.

Baumeister i Benati (2010) su pomoću BVAR modela sagledavali učinak nekonvencionalnih mjera središnjih banaka EMU-a, SAD-a, Japana i Ujedinjenog Kraljevstva na proizvodnju i zaposlenost u razdoblju 2007. - 2009. godine. Autori nalaze snažan doprinos mjera i posebno ističu uspješnost mjera FED-a i BoE-a. Casiraghi, Gaiotti, Rodano i Secchi (2013) primjećuju značajan učinak mjera ESB-a na prinose talijanskih državnih obveznica u 2011. i 2012. godini, te kako je taj utjecaj snažniji kod mjera ESB-a nego u slučaju FEDovih mjera. Osim toga, nekonvencionalnim mjerama ESB-a pripisuju zasluge za deblokiranje bankovnog kreditiranja gospodarstva kroz 2012. i 2013. godinu. Rogers, Scotti i Wright (2014) su, sagledavajući utjecaj nekonvencionalnih mjera FED-a, BoE-a, ESB-a i BoJ-a na cijene imovine, došli do zaključka da te mjere poboljšavaju šire financijske uvjete te preko toga djeluju na ublažavanje proizvodnog jaza i pada stope inflacije ispod zacrtanog praga. Gambacorta, Hofmann i Peersman (2014) su uz pomoć panel VAR modela došli do zaključka da su nekonvencionalne mjere imale učinka na makroekonomske varijable. Primjećuju da su posljedice tih mjera vrlo slične u svim zemljama, iako se radilo o heterogenim zemljama, što su povezali s uspješnim djelovanjima njihovih središnjih banaka u prilagodbi provedenih mjera potrebama svojih gospodarstava. Iako sugeriraju da su te mjere pružile privremeni poticaj svojim gospodarstvima, ipak se ograđuju od zaključka da imaju općenito pozitivne makroekonomske učinke. Darracq-Paries i De Santis (2015) zaključuju kako su trogodišnje operacije refinanciranja (LTRO) ESB-a dale poticaj kanalu bankovnog kreditiranja, te je preko dostupnijih bankovnih kredita pružen doprinos ostvarenju realnog BDP-a. Papadamou, Kyriazis, i Tzeremes (2019) su kroz analizu rezultata 16 istraživanja, koji su primjenjivali VAR metodologiju za mjerenje utjecaja na output i inflaciju, izveli zaključak o slabijoj učinkovitosti nekonvencionalnih mjera ESB-a. To su povezali s nedovoljno jasnim 
karakterom nekonvencionalnih mjera ESB-a, kao i sa slabim kanalom kreditiranja banaka u gospodarstvima europodručja. Gagnon (2016) daje pregled 24 rezultata istraživanja koja su analizirala utjecaj kupnji imovine u SAD, Ujedinjenom Kraljevstvu, Japanu, europodručju i Švedskoj. na snižavanje prinosa na državne obveznice. U pregledu su obuhvaćeni rezultati 16 relevantnih istraživanja na podacima za SAD, 3 na podacima Ujedinjenog Kraljevstva, 1 na podacima za Japan, 3 na podacima za europodručje i 1 na podacima za Švedsku. Analizirana istraživanja su različitih metodoloških pristupa (od studija slučaja do analiza vremenskih serija). Sva istraživanja, iako dolaze do različitih zaključaka o jačini utjecaja, ukazuju na postojanje utjecaja kupnji imovine od strane središnjih banka na snižavanje prinosa na državne obveznice. Autor izvodi zaključak da kvantitativno popuštanje pruža potporu gospodarstvu tijekom financijskog stresa ali i da kupnja imovine daje rezultate i tijekom uobičajenih gospodarskih prilika.

Osim istraživanja provedenih za podatke ESB-a, i istraživanja provedena na podacima za FED, BoE i BoJ potvrđuju teorijski okvir učinaka nekonvencionalnih mjera monetarne politike a koji sugerira kako se izravnim kupnjama financijske imovine od strane središnje banke, a putem transmisijskih kanala (po Hausken i Ncube (2013) to su: kanal uravnoteženja portfelja, kanal signaliziranja, kanal likvidnosti tržišta, kanal očekivanja, kanal bankovnih kredita), brzo i u kratkom roku može djelovati na ključne makroekonomske veličine te da se uz jačanje očekivanja šire javnosti može braniti zemlju od negativnih ekonomskih perspektiva. To je vidljivo u zaključcima Meinusch i Tillmann (2014) koji nalaze da kvantitativno popuštanje utječe na kamatne stope, realne ekonomske varijable, cijene dionica i obveznica te na ukupnu ekonomsku neizvjesnost. Također, i kod rezultata Michaelis i Watzka (2017), na podacima za japansko gospodarstvo, vidljiv je utjecaj nekonvencionalnih mjera tijekom vremena (naročito nakon jasnijeg predstavljanja programa od strane japanskog premijera Shinza Abe). Chen, Cúrdia i Ferrero (2011), kroz analizu FED-ovog LSAP II programa preko DSGE modela, dolaze do zaključka da su učinci programa na rast BDP-a i inflaciju umjereni. D’Amico, English, López-Salido i Nelson (2012) su mjereći učinke FED-ovog prvog i drugog LSAP programa iznijeli zaključak da je LSAP I doveo do smanjenja prinosa na obveznice Riznice za 35, a LSAP II za 45 baznih bodova. Teorijski okvir potvrđuju i nalazi: Christensen i Rudebusch (2012) koji mjere učinke najava kvantitativnog popuštanja u SAD i Ujedinjenom Kraljevstvu; Bridges i Thomas (2012) koji SVAR modelom sagledavaju utjecaj kvantitativnog popuštanja na cijene imovine i nominalnu potrošnju, a preko ponude i potražnje za novcem; Churm, Joyce, Kapetanios i Theodoridis (2018) čiji BVAR model pokazuje da su drugi krug kupnji imovine QE2 i početna faza FLS-a povećali BDP u Velikoj Britaniji za oko 0,5 - 0,8\% tijekom 2011. - 2012. godine, dok je utjecaj na inflaciju bio uglavnom pozitivan i dosegnuo je oko 0,6 \%; te Bhattarai, Eggertsson i Gafarov (2015), koji zaključuju da programi kupnje imovine nisu neutralni budući da povećavaju bilancu središnje banke i produljuju ročnost njezinog portfelja a zašto će sama biti zainteresirana za održavanje niskih kamatnih stopa zarad izbjegavanja gubitaka u svojoj bilanci. Pri zamci likvidnosti nekonvencionalne mjere mogu pomoći u snižavanju dugoročne kamatne stope i stvaranju inflatornih očekivanja a što je od pomoći gospodarstvu da se udalji od situacije deflacije. 


\section{METODOLOGIJA ISTRAŽIVANJA}

Istraživanje se koristi BEAR ekonometrijskim alatom² (BEAR Toolbox), koji su razvili Dieppe et al. (2016) na temelju Arias et al. (2014) metodologije. Alat se primjenjuje za procjenu vektorskih autoregresivnih (VAR) modela. U alatu su dostupne standardne i bayesijanske metode procjene VAR modela. Prilikom izbora bayesijanskih metoda moguće je odabrati različite apriorne distribucije za koeficijente i kovarijacijsku matricu VAR modela. Također, moguce je identificirati ekonomske šokove koristeći se restrikcijama nula i/ili restrikcijama na predznak na parametre VAR modela ili funkcije tih parametara. U praksi se najčešce primjenjuju restrikcije na funkciju impulsnog odziva. Uvođenje restrikcija olakšava procjenu VAR modela s velikim brojem parametara u kratkom vremenskom rasponu. Pojedine parametre VAR modela moguće je ograničiti ili potpuno isključiti koristeći se apriornim distribucijama. Zato pri procjeni VAR modela prednost dajemo bayesijanskim simulacijskim tehnikama.

U ovom se radu za apriornu distribuciju primjenjivala normalna Wishartova distribucija, to jest korištena je normalna distribucija kao apriorna za koeficijente VAR modela, odnosno inverzna Wishartova distribucija kao apriorna za kovarijacijsku matricu. Aposteriorne uvjetne distribucije istog su oblika, to jest parametri VAR modela simulirani su uvjetno na kovarijacijsku matricu iz normalne distribucije, a kovarijacijske matrice VAR modela uvjetno na parametre modela iz inverzne Wishartove distribucije. Kako bi se dobio uzorak parametara VAR modela i kovarijacijskih matrica iz prave aposteriorne distribucije, primjenjuje se Gibbsov algoritam uzorkovanja. Takav algoritam podrazumijeva da uzorak simuliran iz uvjetnih distribucija, dobiven nakon velikog broja simulacija, odgovara uzorku iz prave aposteriorne distribucije. Prilikom identifikacije ekonomskih šokova upotrebom restrikcija nula i restrikcija na predznak, simuliranjem zadržavamo samo one elemente uzorka koji zadovoljavaju zadane restrikcije.

Simulacijske tehnike koje su razvili Arias, Rubio-Ramirez i Waggoner $(2014,2018)$ mogu se primijeniti u slučaju nultih restrikcija i restrikcija na predznak na bilo koju funkciju G koja preslikava strukturne parametre u prostor $\mathrm{r}$ x n matrica:

$$
G:\left(A_{0}, A_{+}\right) \rightarrow R^{(r \times n)} .
$$

Preslikavanje G zadovoljava uvjet ortogonalnosti:

$$
G\left(A_{0} Q, A_{+} Q\right)=G\left(A_{0}, A_{+}\right) Q
$$

U slučaju nultih restrikcija tehnike uzorkovanja zahtijevaju i dodatan uvjet regularnosti. To znači da je funkcija $G$ diferencijabilna i da je njezina prva derivacija punog ranga po redcima.

Postoje različite reprezentacije VAR modela, od kojih su najčešće reducirana, strukturna i reprezentacija impulsnog odziva. Radi jednostavnosti, parametri VAR modela najče-

European Central Bank BEAR Toolbox [online]. Dostupno na https://www.ecb.europa.eu/pub/research/ working-papers/html/bear-toolbox.en.html [30. prosinca 2018.] 
šće se simuliraju u reduciranoj reprezentaciji. Međutim, za zadane parametre reduciranog VAR modela ne postoji jedinstveno rješenje za strukturne parametre. To predstavlja identifikacijski problem VAR modela. U literaturi se često primjenjuje rekurzivna identifikacija (Cholesky) ekonomskih šokova. Tako identificirani šokovi nemaju jasnu ekonomsku interpretaciju. Stoga se uvode restrikcije na strukturne parametre modela ili na neku funkciju strukturnih parametara modela, poput funkcije impulsnog odziva. Na primjer, možemo uzeti element funkcije impulsnog odziva koji predstavlja reakciju pojedine varijable na neki strukturni šok. Učinimo li taj element jednakim nuli, eliminirali smo utjecaj strukturnog šoka na promatranu varijablu u danom vremenskom trenutku. Tada govorimo o nultim restrikcijama. Učinimo li taj element pozitivnim ili negativnim, govorimo o restrikcijama na predznak. Kombinacijom nultih restrikcija i restrikcija na predznak mogu se identificirati šokovi s jasnom ekonomskom interpretacijom.

Pri svakoj se simulaciji reducirana reprezentacija najprije transformira u reprezentaciju impulsnog odziva kako bi se provjerila zadovoljenost postavljenih restrikcija. Jedan od praktičnih problema jest simulirati uzorak koji zadovoljava restrikcije nula. To se postiže uvođenjem ortogonalne reducirane reprezentacije, to jest uvođenjem ortogonalne matrice zajedno s reduciranom reprezentacijom. Kako bismo prikazali medijane reprezentacije impulsnog odziva i historijske dekompozicije, potrebno je transformirati uzorak u reduciranoj reprezentaciji tako da odgovara nezavisno simuliranom uzorku u strukturnoj reprezentaciji.

Prema Arias, Rubio-Ramirez i Waggoner (2018) dovoljan uvjet za identifikaciju jest postojanje poretka strukturnih šokova takvog da funkcija impulsnog odziva na j-ti strukturni šok sadržava barem n-j nultih restrikcija i barem jednu restrikciju predznaka. Ako je taj uvjet zadovoljen samo za prvih nekoliko strukturnih šokova, možemo smatrati da su ti šokovi identificirani. Nužan uvjet identifikacije jest da je broj nultih restrikcija veći ili jednak $\mathrm{n} \times(\mathrm{n}-1) / 2$.

Za identifikaciju šoka nekonvencionalne monetarne politike potrebno je da su, u trenutku djelovanja šoka $(t=0)$, zadovoljene sljedeće restrikcije na funkciju impulsnog odziva:

- povećava se aktiva ESB-a (zadovoljena je restrikcija na predznak +),

- snižava se tržišna kamatna stopa (zadovoljena je restrikcija na predznak -),

- snižava se vrijednost CISS indeksa (zadovoljena je restrikcija na predznak -),

- ne mijenja se referentna kamatna stopa ESB-a (zadovoljena je restrikcija 0).

Nakon identifikacije ekonomskih šokova praktično je dekomponirati vrijednosti endogenih varijabli u svakom trenutku na doprinose pojedinih šokova i inicijalni doprinos ostalih varijabli VAR modela. Takva reprezentacija naziva se historijskom dekompozicijom.

Matematički zapis modela glasi:

$$
Y_{t}^{T} A_{0}=C+Y_{t-1}^{T} A_{1}+\ldots+Y_{t-p}^{T} A_{p}+\varepsilon_{t}^{T}
$$

gdje su: $Y_{t}$ - vektor endogenih varijabli reda $\mathrm{n} \times 1, \mathrm{C}-$ konstantan vektor reda $\mathrm{n} \times 1, A_{i}-$ matrice strukturnih parametara $\left((i \in\{1, \ldots, p\})\right.$, svaka reda $\mathrm{n} \times \mathrm{n}$, te $\varepsilon_{t}-$ vektor strukturnih šokova reda n x 1 . Model se može skraćeno zapisati u sljedećem obliku:

$$
Y_{t}^{T} A_{0}=X_{t}^{T} A_{+}+\varepsilon_{t}^{T}
$$


pri čemu je $X_{t}^{T}=\left(Y_{t-1}^{T} \ldots Y_{t-p}^{T}\right)$ i $A_{+}^{T}=\left(A_{1}^{T} \ldots A_{p}^{T}\right)$.

$\left(A_{0}, A_{+}\right)$je strukturna reprezentacija procesa, pri čemu je $A_{0}$ matrica reda $\mathrm{n}$ x $\mathrm{n}$, dok je $A_{+}$ matrica parametara reda $\mathrm{n} \cdot \mathrm{p}$ x n. Množenjem relacije (3.2) sa $A_{0}^{-1}$ zdesna dobiva se:

$$
Y_{t}^{T}=X_{t}^{T} B+u_{t}^{T}
$$

pri čemu je B $=A_{+} A_{0}^{-1}, u_{t}^{T}=\varepsilon_{t}^{T} A_{0}^{-1}$ i $\mathrm{E}\left[u_{t} u_{t}^{T}\right]=\left(A_{0} A_{0}^{T}\right)^{-1}=\Sigma$.

$(\mathrm{B}, \Sigma)$ je reducirana reprezentacija procesa, pri čemu je B matrica reduciranih parametara reda $\mathrm{n} \cdot \mathrm{p}$ x n, dok je $\Sigma$ simetrična matrica reda $\mathrm{n}$ x n. Množenjem relacije (3.3) ortogonalnom matricom $\mathrm{Q}$ dobiva se:

$$
\begin{gathered}
Y_{t}^{T} A_{0} Q=X_{t}^{T} A_{+} Q+\varepsilon_{t}^{T} Q \\
Y_{t}^{T}=X_{t}^{T} \tilde{A}_{+} \tilde{A}_{0}^{-1}+\tilde{\varepsilon}_{t}^{T} \tilde{A}_{0}^{-1} \\
Y_{t}^{T}=X_{t}^{T} \widetilde{B}+\tilde{u}_{t}^{T}
\end{gathered}
$$

pri čemu je $\tilde{A}_{0}=A_{0} Q, \tilde{A}_{+}=A_{+} Q, \tilde{\varepsilon}_{t}^{T}=\varepsilon_{t}^{T} Q$, odnosno $\tilde{B}=\tilde{A}_{+} \tilde{A}_{0}^{-1} \mathrm{i} \tilde{u}_{t}^{T}=\tilde{\varepsilon}_{t}^{T} \tilde{A}_{0}^{-1}$.

Dakle, vrijedi sljedeće:

$$
\begin{gathered}
\widetilde{B}=\widetilde{A}_{+} \widetilde{A}_{0}^{-1}=A_{+} Q Q^{-1} A_{0}^{-1}=A_{+} I A_{0}^{-1}=B \\
\widetilde{\Sigma}=E \quad \tilde{u}_{t} \tilde{u}_{t}^{T}=\left(Q^{-1} A_{0}^{-1}\right)^{T} E \quad \tilde{\varepsilon}_{t} \tilde{\varepsilon}_{T}^{t} \quad Q^{-1} A_{0}^{-1}=\left(A_{0} A_{0}^{T}\right)^{-1}=\Sigma .
\end{gathered}
$$

Time smo pokazali da, ako postoji ortogonalna transformacija, koja transformira jednu strukturnu reprezentaciju u drugu, onda te dvije strukturne reprezentacije imaju istu reduciranu reprezentaciju.

VAR može biti zapisan u ortogonalnoj reduciranoj reprezentaciji (B, $\Sigma$, Q), koja je karakterizirana reduciranim parametrima: $(\mathrm{B}, \Sigma)$ zajedno s ortogononalnom matricom Q.

Odziv i-te varijable modela na j-ti strukturni šok u konačnom vremenskom trenutku $\mathrm{h}$ odgovara elementu matrice $L_{h}$ koji se nalazi u i-tom retku i j-tom stupcu:

$$
L_{h}\left(A_{0}, A_{+}\right)=\left(A_{0}^{-1} J^{T} F^{h} J\right)^{T}
$$

$L_{h}$ predstavlja reprezentaciju impulsnog odziva, pri čemu su matrice $F$ i $J$ definirane sljedećim relacijama:

$$
F=\left(\begin{array}{cccc}
A_{1} A_{0}^{-1} & I_{n} & \cdots & 0 \\
\vdots & \vdots & \ddots & \vdots \\
\vdots & 0 & \cdots & I_{n} \\
A_{p} A_{0}^{-1} & 0 & \cdots & 0
\end{array}\right)
$$


Historijska dekompozicija može se zapisati u sljedećem obliku:

$$
y_{t}=J^{T}\left(F^{T}\right)^{t} \tilde{y}_{0}+\sum_{h=0}^{t-1} L_{h} \varepsilon_{t-h}
$$

Model uključuje varijable: 1) IND - stopa industrijske proizvodnje (izvor: World Bank/ DataBank/GEM), 2) NEZ - stopa nezaposlenosti (izvor: ECB SDW), 3) KRED - krediti banaka (domaćí bankovni krediti plasirani nemonetarnim financijskim institucijama (engl. Non-MFI) isključujući državu; izvor: ECB SDW), 4) OBV - prinos na desetogodišnje obveznice (izvor: IMF IFS, nacionalni podaci), 5) BUR - burzovni indeks (izvor: Bloomberg), 6) IZVOZ - izvoz (izvor: IMF DOTS), 7) ESB - aktiva ESB (izvor: ECB SDW), 8) CISS - CISS indeks (indikator razine stresa na financijskim tržištima, izvor: ECB SDW), 9) TKS - tržišna kamatna stopa (izvor: OECD Data) i 10) RKS - referentna kamatna stopa (izvor: BIS/statistics/cbpol). Prvih 6 varijabli modela su indikatori kretanja realnog i financijskog dijela gospodarstva svih zemalja uzorka. Preostale 4 varijable su indikatori monetarne politike jer se preko njih pomoću zadanih restrikcija identificiraju nekonvencionalne mjere monetarne politike. Kako je cilj istraživanja sagledati učinkovitost nekonvencionalnih mjera ESB-a na europski monetarni prostor, u uzorak ulazi 19 zemalja europodručja: Njemačka, Francuska, Italija, Španjolska, Nizozemska, Belgija, Luksemburg, Austrija, Irska, Portugal, Grčka, Letonija, Litva, Estonija, Finska, Malta, Cipar, Slovačka i Slovenija. Period promatranja je 2008m1 - 2017m12. Podaci su mjesečni. Prikupljeni su sekundarni podaci iz vjerodostojnih izvora. Postojanost izvornog modela provjerena je zamjenom varijable ukupne aktive ESB-a sa stavkom 7.1. aktive „Vrijednosni papiri držani za potrebe monetarne politike“ te izmjenom broja lagova sa 2 na 4.

\section{REZULTATI I DISKUSIJA}

Rezultati istraživanja izlažu se na dva načina.

Uvodno se slikama $2-7$ prikazuju rezultati funkcije historijske dekompozicije koje pokazuju koliki je doprinos šoka aktive ESB-a fluktuaciji promatranih varijabli zemalja uzorka. Ti se rezultati prikazuju grafički i skupno za sve zemlje ne bi li se uočili zajednički periodi u promatranom razdoblju kad je šok ESB-a značajnije doprinio fluktuaciji pojedine varijable. Potom se tablicama $1-6$ ističe godišnja procentualna promjena pojedine varijable svih zemalja uzorka. Na taj se način identificiraju periodi vremena u kojima su varijable intenzivnije fluktuirale u promatranom razdoblju. Usporedbom tih perioda s onima na koje ukazuju rezultati funkcije historijske dekompozicije izloženi na slikama 2 - 7 želi se utvrditi postoji li globalno (za sve zemlje uzorka) vremensko poklapanje ili korelacija između doprinosa šoka promjene aktive ESB-a i promjena varijabli promatranih zemalja.

U nastavku se, potom, izlažu rezultati za svih 19 provedenih modela, po svakoj članici europodručja. $U$ tom prikazu ističe se utjecaj na realne varijable, zatim financijske te s naglaskom na kanale transmisije šokova.

Slika 1 i tablica 1, s prikazom postotne mjesečne i godišnje promjene aktive središnje banke, ističu dva perioda izrazitog rasta aktive: 1) $2011 \mathrm{m8} \mathrm{-} \mathrm{2012m8} \mathrm{-} \mathrm{kada} \mathrm{je} \mathrm{aktiva} \mathrm{narasla} 58 \%$ u tih 12 mjeseci, a $190 \%$ u odnosu na početak promatranog razdoblja, 2) 2014m11 - do kraja promatranog razdoblja - kada je aktiva, nakon perioda smanjenja 2012 m9 - 2014m10, ponovno snažno rasla sa $90 \%$ na $280 \%$ u odnosu na početak promatranog razdoblja. 


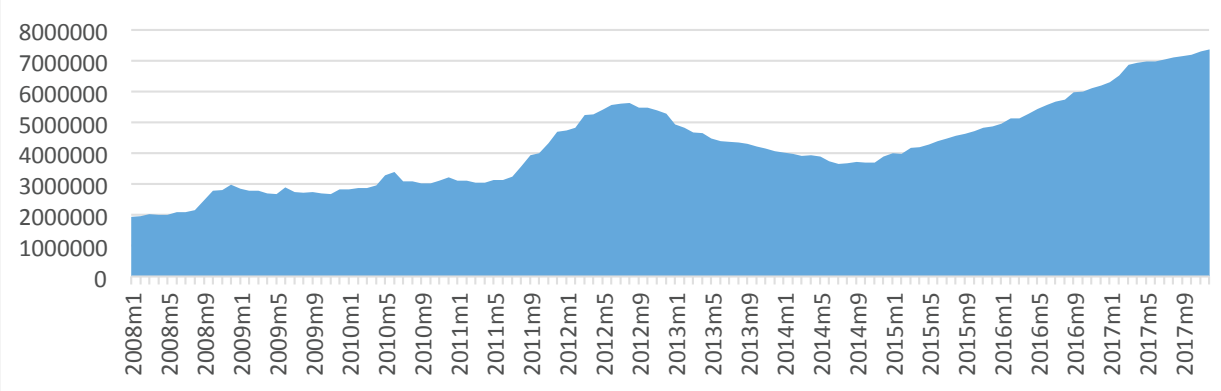

Slika 1. Rast aktive ESB-a u promatranom razdoblju (1./2008. - 12./2017., u milijunima EUR)

Izvor: izrada autora i statistički podaci iz baze European Central Bank Statistical Data Warehouse (SDW)

Rezultati funkcije historijske dekompozicije (Slike 2 - 7) ukazuju na značajan doprinos šoka aktive ESB-a i kroz dva perioda intenzivnog rasta aktive, ali i u periodu smanjenja aktive od kraja 2012. do kraja 2014. godine, za varijable industrijske proizvodnje, nezaposlenosti, izvoza, burzovne fluktuacije i obvezničkih prinosa kod zemalja uzorka.

Industrijska proizvodnja: postotna promjena međumjesečne stope industrijske proizvodnje pokazuje: 1) $2012 \mathrm{ml}$ - samo Grčka i Irska imaju negativnu promjenu, 2) 2013m1 - 11 zemalja ima negativnu promjenu, 3) 2014m1 - 14 zemalja ima negativnu promjenu, 3) 2015m1- 5 zemalja ima negativnu promjenu, 4) 2016m1 - četiri zemlje imaju negativnu promjenu, 5) 2017m1 - 6 zemalja ima negativnu promjenu, 6) 2017m12- samo Luksemburg ima negativnu promjenu. Usporedbom ovih presjeka s periodima promjene aktive ESB-a vidljivo je da je tijekom dvaju perioda izrazitog rasta aktive industrijska proizvodnja imala pozitivnu tendenciju promjene u većini zemalja, dok je između tih dvaju perioda, kada se aktiva smanjivala, većina zemalja imala negativnu tendenciju promjene stope industrijske proizvodnje. Pozitivni doprinos šoka aktive ESB-a vidljiv je od kraja 2012. do kraja 2014. godine, te od 2017. godine (slika 2).

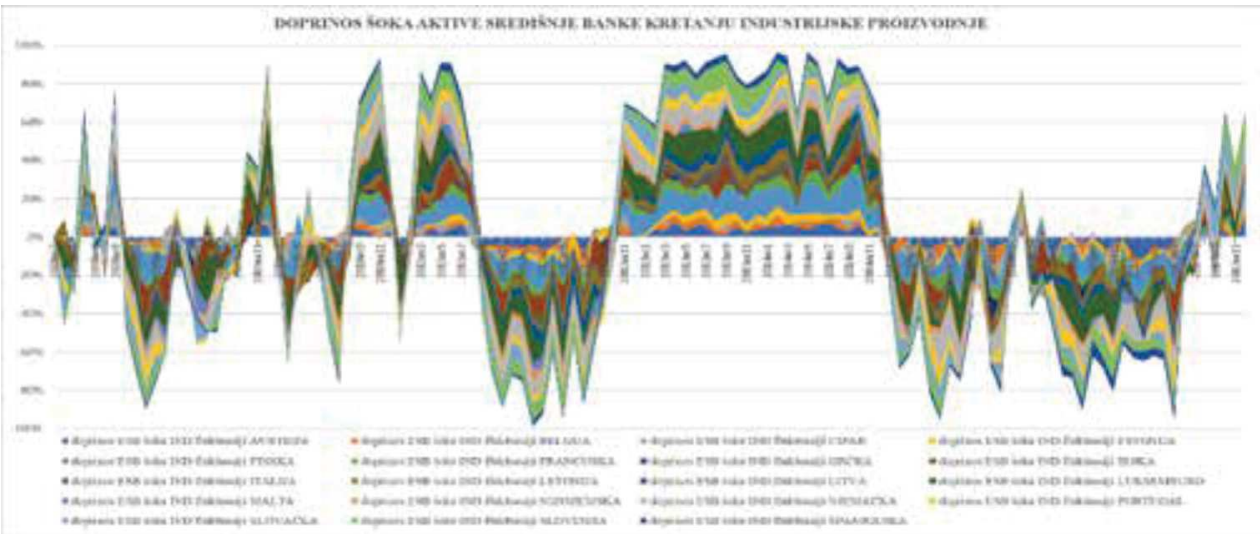

Slika 2. Doprinos šoka promjene aktive ESB-a fluktuaciji industrijske proizvodnje

Izvor: izrada autora

Napomena: rezultati modela, funkcija historijske dekompozicije, sve promatrane zemlje 
Tablica 1. godišnje promjene aktive ESB-a i stope industrijske proizvodnje

\begin{tabular}{|c|c|c|c|c|c|c|c|c|c|c|c|}
\hline ESB & $2008 \mathrm{~m} 1$ & $2009 \mathrm{~m} 1$ & $2010 \mathrm{~m} 1$ & $2011 \mathrm{~m} 1$ & $2012 \mathrm{~m} 1$ & $2013 \mathrm{~m} 1$ & $2014 \mathrm{~m} 1$ & 2015m1 & $2016 \mathrm{ml}$ & $2017 \mathrm{~m} 1$ & $2017 \mathrm{~m} 12$ \\
\hline $\begin{array}{c}\text { \% povećanje } \\
\text { aktive od početka } \\
\text { perioda } \\
\end{array}$ & & $46 \%$ & $46 \%$ & $60 \%$ & $144 \%$ & $154 \%$ & $107 \%$ & $106 \%$ & $156 \%$ & $225 \%$ & $280 \%$ \\
\hline $\begin{array}{c}\% \text { povećanje } \\
\text { aktive u } 1 \text { godini }\end{array}$ & & $46 \%$ & $-1 \%$ & $10 \%$ & $53 \%$ & $4 \%$ & $-18 \%$ & $0 \%$ & $24 \%$ & $27 \%$ & $17 \%$ \\
\hline \begin{tabular}{|c|}
$\%$ povećanje \\
aktive u 2 godine
\end{tabular} & & & $46 \%$ & & $68 \%$ & & $-15 \%$ & & $23 \%$ & & $48 \%$ \\
\hline \multicolumn{12}{|c|}{$\%$ promjene industrijske proizvodnje u jednoj godini } \\
\hline AUSTRIJA & & $-10 \%$ & $-2 \%$ & $12 \%$ & $0 \%$ & $1 \%$ & $2 \%$ & $1 \%$ & $4 \%$ & $0 \%$ & $8 \%$ \\
\hline BELGIJA & & $-14 \%$ & $6 \%$ & $8 \%$ & $0 \%$ & $-4 \%$ & $4 \%$ & $1 \%$ & $4 \%$ & $-2 \%$ & $5 \%$ \\
\hline CIPAR & & $1 \%$ & $-9 \%$ & $-6 \%$ & $0 \%$ & $-9 \%$ & $-19 \%$ & $-4 \%$ & $2 \%$ & $12 \%$ & $5 \%$ \\
\hline ESTONIJA & & $0 \%$ & $-22 \%$ & $5 \%$ & $30 \%$ & $2 \%$ & $5 \%$ & $3 \%$ & $5 \%$ & $-4 \%$ & $8 \%$ \\
\hline FINSKA & & $-3 \%$ & $-17 \%$ & $-2 \%$ & $7 \%$ & $-3 \%$ & $-2 \%$ & $-2 \%$ & $-3 \%$ & $4 \%$ & $4 \%$ \\
\hline FRANCUSKA & & $1 \%$ & $-17 \%$ & $3 \%$ & $7 \%$ & $-3 \%$ & $-2 \%$ & $0 \%$ & $1 \%$ & $1 \%$ & $0 \%$ \\
\hline GRČKA & & $-7 \%$ & $-6 \%$ & $-9 \%$ & $-3 \%$ & $-6 \%$ & $-3 \%$ & $0 \%$ & $2 \%$ & $-4 \%$ & $11 \%$ \\
\hline IRSKA & & $0 \%$ & $-3 \%$ & $6 \%$ & $-1 \%$ & $-1 \%$ & $-5 \%$ & $16 \%$ & $53 \%$ & $-9 \%$ & $2 \%$ \\
\hline ITALIJA & & $-1 \%$ & $-22 \%$ & $3 \%$ & $6 \%$ & $-6 \%$ & $-4 \%$ & $0 \%$ & $-1 \%$ & $2 \%$ & $2 \%$ \\
\hline LETONIJA & & $4 \%$ & $-25 \%$ & $5 \%$ & $12 \%$ & $13 \%$ & $-4 \%$ & $1 \%$ & $0 \%$ & $4 \%$ & $10 \%$ \\
\hline LITVA & & $0 \%$ & $-13 \%$ & $1 \%$ & $12 \%$ & $0 \%$ & $5 \%$ & $0 \%$ & $5 \%$ & $5 \%$ & $5 \%$ \\
\hline LUKSEMBURG & & $4 \%$ & $-28 \%$ & $10 \%$ & $11 \%$ & $-8 \%$ & $-7 \%$ & $8 \%$ & $-2 \%$ & $6 \%$ & $-5 \%$ \\
\hline \begin{tabular}{|l|} 
MALTA \\
\end{tabular} & & $10 \%$ & $-25 \%$ & $4 \%$ & $9 \%$ & $3 \%$ & $-7 \%$ & $-7 \%$ & $4 \%$ & $-3 \%$ & $8 \%$ \\
\hline NIZOZEMSKA & & $1 \%$ & $-9 \%$ & $7 \%$ & $4 \%$ & $0 \%$ & $-1 \%$ & $-5 \%$ & $3 \%$ & $-1 \%$ & $2 \%$ \\
\hline NJEMAČKA & & $0 \%$ & $-21 \%$ & $7 \%$ & $14 \%$ & $1 \%$ & $-2 \%$ & $3 \%$ & $1 \%$ & $2 \%$ & $1 \%$ \\
\hline PORTUGAL & & $0 \%$ & $-18 \%$ & $2 \%$ & $1 \%$ & $-7 \%$ & $-2 \%$ & $5 \%$ & $-2 \%$ & $5 \%$ & $1 \%$ \\
\hline SLOVAČKA & & $3 \%$ & $-23 \%$ & $6 \%$ & $13 \%$ & $4 \%$ & $-3 \%$ & $5 \%$ & $3 \%$ & $11 \%$ & $1 \%$ \\
\hline SLOVENIJA & & $1 \%$ & $-21 \%$ & $4 \%$ & $5 \%$ & $-2 \%$ & $3 \%$ & $-4 \%$ & $7 \%$ & $7 \%$ & $8 \%$ \\
\hline ŠPANJOLSKA & & $-1 \%$ & $-21 \%$ & $-2 \%$ & $3 \%$ & $-7 \%$ & $-5 \%$ & $3 \%$ & $1 \%$ & $3 \%$ & $3 \%$ \\
\hline
\end{tabular}

Izvor: izračun autora, World Bank Databank (GEM) i statistički podaci iz baze ECB Statistical Data Warehouse (SDW)

Nezaposlenost: I kod varijable nezaposlenosti uočava se značajan doprinos šoka aktive ESB-a i kroz dva perioda intenzivnog rasta aktive, ali i u periodu smanjenja aktive. Slika 3 ukazuje na statistički negativan (ekonomski pozitivan) doprinos šoka aktive fluktuaciji stope nezaposlenosti od zadnjeg kvartala 2012. do početka 2015. godine. 


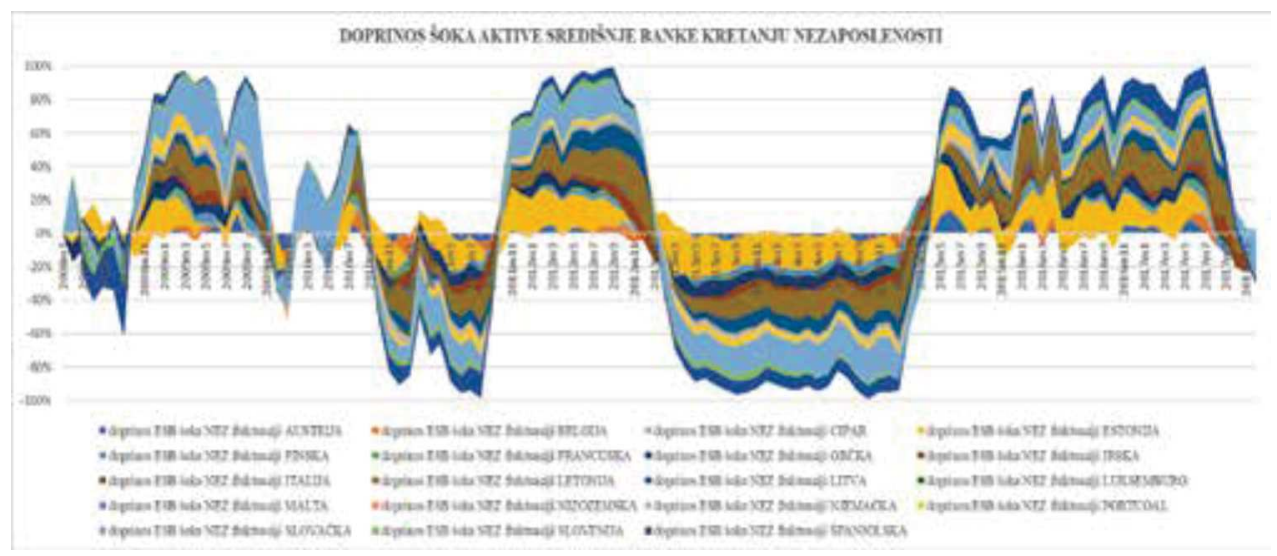

Slika 3. Doprinos šoka promjene aktive ESB-a fluktuaciji nezaposlenosti

Izvor: izrada autora

Napomena: rezultati modela, funkcija historijske dekompozicije, sve promatrane zemlje

Usporedbom postotne mjesečne promjene stope nezaposlenosti s periodima intenzivne promjene aktive uočava se da je u periodima intenzivnog rasta aktive uglavnom došlo do snižavanja stope nezaposlenosti, dok je u periodu smanjenja aktive stopa nezaposlenosti ili usporila pad ili se povećala.

Tablica 2. Godišnje promjene stope nezaposlenosti

\begin{tabular}{|c|r|r|r|r|r|r|r|r|r|r|}
\hline NEZ & $2009 \mathrm{~m} 1$ & $2010 \mathrm{~m} 1$ & $2011 \mathrm{~m} 1$ & $2012 \mathrm{~m} 1$ & $2013 \mathrm{~m} 1$ & $2014 \mathrm{~m} 1$ & $2015 \mathrm{~m} 1$ & $2016 \mathrm{~m} 1$ & $2017 \mathrm{~m} 1$ & $2017 \mathrm{~m} 12$ \\
\hline AUSTRIJA & $10 \%$ & $11 \%$ & $-6 \%$ & $-7 \%$ & $15 \%$ & $7 \%$ & $-1 \%$ & $10 \%$ & $-5 \%$ & $-5 \%$ \\
\hline BELGIJA & $5 \%$ & $15 \%$ & $-15 \%$ & $-2 \%$ & $18 \%$ & $3 \%$ & $-1 \%$ & $-2 \%$ & $-10 \%$ & $-18 \%$ \\
\hline CIPAR & $-2 \%$ & $72 \%$ & $0 \%$ & $53 \%$ & $48 \%$ & $6 \%$ & $6 \%$ & $-22 \%$ & $-4 \%$ & $-18 \%$ \\
\hline ESTONIJA & $138 \%$ & $77 \%$ & $-19 \%$ & $-25 \%$ & $-9 \%$ & $-12 \%$ & $-26 \%$ & $-1 \%$ & $-9 \%$ & $-5 \%$ \\
\hline FINSKA & $9 \%$ & $23 \%$ & $-7 \%$ & $-6 \%$ & $6 \%$ & $5 \%$ & $8 \%$ & $2 \%$ & $-5 \%$ & $-5 \%$ \\
\hline FRANCUSKA & $13 \%$ & $12 \%$ & $-1 \%$ & $3 \%$ & $9 \%$ & $-1 \%$ & $1 \%$ & $-2 \%$ & $-5 \%$ & $-6 \%$ \\
\hline GRČKA & $16 \%$ & $22 \%$ & $37 \%$ & $43 \%$ & $24 \%$ & $2 \%$ & $-5 \%$ & $-6 \%$ & $-5 \%$ & $-10 \%$ \\
\hline IRSKA & $91 \%$ & $37 \%$ & $11 \%$ & $4 \%$ & $-9 \%$ & $-12 \%$ & $-17 \%$ & $-16 \%$ & $-18 \%$ & $-17 \%$ \\
\hline ITALIJA & $10 \%$ & $16 \%$ & $-4 \%$ & $19 \%$ & $23 \%$ & $8 \%$ & $-3 \%$ & $-7 \%$ & $1 \%$ & $-7 \%$ \\
\hline LETONIJA & $100 \%$ & $66 \%$ & $-17 \%$ & $-10 \%$ & $-16 \%$ & $-12 \%$ & $-15 \%$ & $3 \%$ & $-8 \%$ & $-13 \%$ \\
\hline LITVA & $134 \%$ & $69 \%$ & $3 \%$ & $-19 \%$ & $-10 \%$ & $-7 \%$ & $-17 \%$ & $-15 \%$ & $-3 \%$ & $-15 \%$ \\
\hline LUKSEMBURG & $25 \%$ & $-14 \%$ & $2 \%$ & $5 \%$ & $12 \%$ & $9 \%$ & $4 \%$ & $2 \%$ & $-6 \%$ & $-8 \%$ \\
\hline MALTA & $5 \%$ & $11 \%$ & $-6 \%$ & $-5 \%$ & $-8 \%$ & $1 \%$ & $-6 \%$ & $-3 \%$ & $-22 \%$ & $-3 \%$ \\
\hline NIZOZEMSKA & $-3 \%$ & $36 \%$ & $-3 \%$ & $11 \%$ & $20 \%$ & $17 \%$ & $-7 \%$ & $-11 \%$ & $-17 \%$ & $-18 \%$ \\
\hline NJEMAČKA & $-8 \%$ & $1 \%$ & $-14 \%$ & $-14 \%$ & $-2 \%$ & $-4 \%$ & $-6 \%$ & $-8 \%$ & $-12 \%$ & $-8 \%$ \\
\hline PORTUGAL & $11 \%$ & $18 \%$ & $8 \%$ & $17 \%$ & $22 \%$ & $-15 \%$ & $-8 \%$ & $-12 \%$ & $-16 \%$ & $-21 \%$ \\
\hline SLOVAČKA & $-7 \%$ & $56 \%$ & $-7 \%$ & $0 \%$ & $3 \%$ & $-3 \%$ & $-11 \%$ & $-15 \%$ & $-17 \%$ & $-13 \%$ \\
\hline SLOVENIJA & $11 \%$ & $18 \%$ & $8 \%$ & $17 \%$ & $22 \%$ & $-15 \%$ & $-8 \%$ & $-12 \%$ & $-16 \%$ & $-21 \%$ \\
\hline ŠPANJOLSKA & $74 \%$ & $21 \%$ & $7 \%$ & $14 \%$ & $13 \%$ & $-3 \%$ & $-8 \%$ & $-12 \%$ & $-10 \%$ & $-10 \%$ \\
\hline
\end{tabular}

Izvor: izračun autora i statistički podaci iz baze European Central Bank Statistical Data Warehouse (SDW)

Izvoz: Šok aktive značajno doprinosi fluktuaciji izvoza u periodima rasta i smanjenja aktive. Slike 2 i 4 vrlo su slične, što sugerira da je šok aktive imao sličan doprinos varijabli izvoza kao i varijabli industrijske proizvodnje sa snažnim pozitivnim doprinosom od zadnjeg kvartala 2012. do početka 2015. godine. 


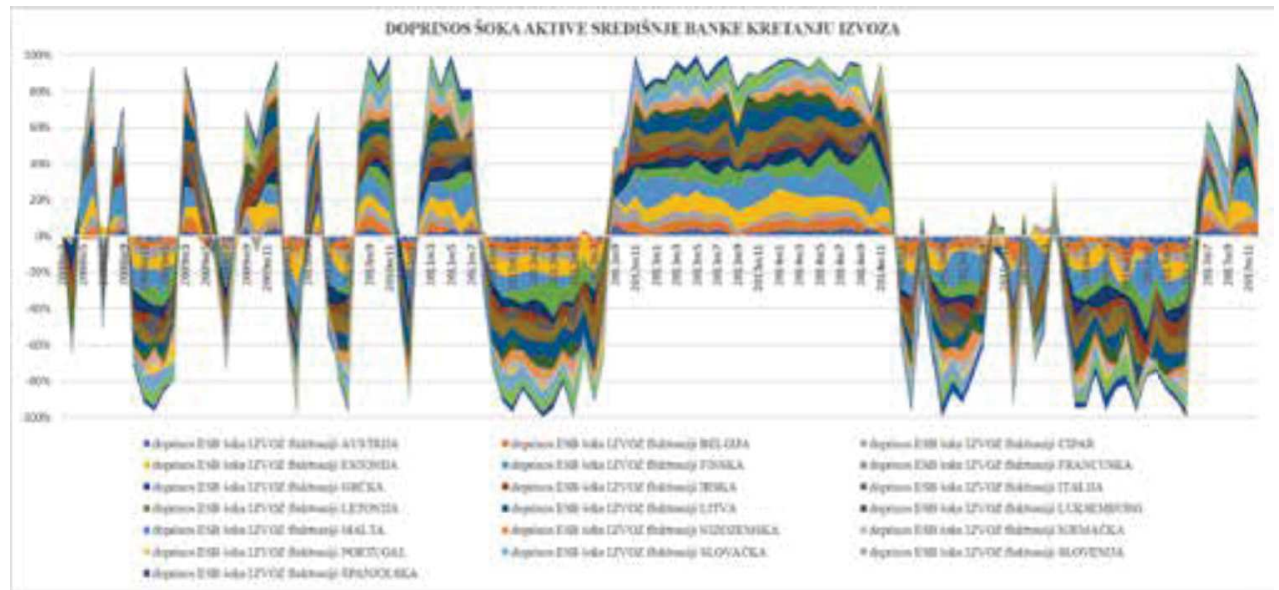

Slika 4. Doprinos šoka promjene aktive ESB-a fluktuaciji izvoza

Izvor: izrada autora

Napomena: rezultati modela, funkcija historijske dekompozicije, sve promatrane zemlje

Kod varijable izvoza slabije je poklapanje perioda rasta aktive s rastom izvoza. Izvoz je u većini zemalja rastao u periodu 2013. - 2014. te u 2017. godini pa bi to moglo upućivati na kašnjenje učinaka nekonvencionalnih mjera na izvoz.

Tablica 3. Kretanje izvoza u promatranom razdoblju

\begin{tabular}{|c|r|r|r|r|r|r|r|r|r|r|}
\hline IZVOZ & $2009 \mathrm{~m} 1$ & $2010 \mathrm{~m} 1$ & $2011 \mathrm{~m} 1$ & $2012 \mathrm{~m} 1$ & $2013 \mathrm{~m} 1$ & $2014 \mathrm{~m} 1$ & $2015 \mathrm{~m} 1$ & $2016 \mathrm{~m} 1$ & $2017 \mathrm{~m} 1$ & $2017 \mathrm{~m} 12$ \\
\hline AUSTRIJA & $-28 \%$ & $4 \%$ & $20 \%$ & $0 \%$ & $7 \%$ & $1 \%$ & $-19 \%$ & $-6 \%$ & $10 \%$ & $16 \%$ \\
\hline BELGIJA & $-34 \%$ & $16 \%$ & $13 \%$ & $0 \%$ & $5 \%$ & $-1 \%$ & $-23 \%$ & $-9 \%$ & $15 \%$ & $18 \%$ \\
\hline CIPAR & $-27 \%$ & $8 \%$ & $1 \%$ & $-17 \%$ & $-1 \%$ & $19 \%$ & $-25 \%$ & $3 \%$ & $11 \%$ & $64 \%$ \\
\hline ESTONIJA & $-43 \%$ & $11 \%$ & $26 \%$ & $14 \%$ & $42 \%$ & $-11 \%$ & $-24 \%$ & $-4 \%$ & $48 \%$ & $-5 \%$ \\
\hline FINSKA & $-36 \%$ & $2 \%$ & $22 \%$ & $-4 \%$ & $21 \%$ & $-4 \%$ & $-19 \%$ & $-9 \%$ & $10 \%$ & $35 \%$ \\
\hline FRANCUSKA & $-26 \%$ & $9 \%$ & $13 \%$ & $-1 \%$ & $5 \%$ & $1 \%$ & $-17 \%$ & $-8 \%$ & $12 \%$ & $-92 \%$ \\
\hline GRČKA & $-27 \%$ & $0 \%$ & $-16 \%$ & $-8 \%$ & $-3 \%$ & $1 \%$ & $-15 \%$ & $-13 \%$ & $9 \%$ & $35 \%$ \\
\hline IRSKA & $-39 \%$ & $-14 \%$ & $26 \%$ & $13 \%$ & $38 \%$ & $1 \%$ & $-25 \%$ & $3 \%$ & $107 \%$ & $-15 \%$ \\
\hline ITALIJA & $-36 \%$ & $14 \%$ & $10 \%$ & $-7 \%$ & $8 \%$ & $1 \%$ & $-15 \%$ & $-6 \%$ & $6 \%$ & $23 \%$ \\
\hline LETONIJA & $-43 \%$ & $-8 \%$ & $42 \%$ & $33 \%$ & $14 \%$ & $-4 \%$ & $-23 \%$ & $-12 \%$ & $23 \%$ & $37 \%$ \\
\hline LITVA & $-47 \%$ & $-2 \%$ & $64 \%$ & $-1 \%$ & $23 \%$ & $14 \%$ & $-22 \%$ & $-4 \%$ & $19 \%$ & $42 \%$ \\
\hline LUKSEMBURG & $-28 \%$ & $12 \%$ & $14 \%$ & $-1 \%$ & $5 \%$ & $3 \%$ & $-25 \%$ & $-10 \%$ & $11 \%$ & $22 \%$ \\
\hline MALTA & $-21 \%$ & $9 \%$ & $17 \%$ & $-9 \%$ & $7 \%$ & $-13 \%$ & $-7 \%$ & $-7 \%$ & $25 \%$ & $27 \%$ \\
\hline NIZOZEMSKA & $-30 \%$ & $13 \%$ & $8 \%$ & $1 \%$ & $9 \%$ & $2 \%$ & $-17 \%$ & $-7 \%$ & $13 \%$ & $20 \%$ \\
\hline NJEMAČKA & $-23 \%$ & $5 \%$ & $13 \%$ & $1 \%$ & $6 \%$ & $6 \%$ & $-17 \%$ & $-4 \%$ & $7 \%$ & $14 \%$ \\
\hline PORTUGAL & $-9 \%$ & $7 \%$ & $5 \%$ & $-10 \%$ & $0 \%$ & $13 \%$ & $-17 \%$ & $-7 \%$ & $15 \%$ & $22 \%$ \\
\hline SLOVAČKA & $-27 \%$ & $1 \%$ & $30 \%$ & $-2 \%$ & $23 \%$ & $11 \%$ & $-12 \%$ & $-4 \%$ & $6 \%$ & $15 \%$ \\
\hline SLOVENIJA & $-37 \%$ & $8 \%$ & $14 \%$ & $0 \%$ & $11 \%$ & $-4 \%$ & $-14 \%$ & $-9 \%$ & $21 \%$ & $13 \%$ \\
\hline ŠPANJOLSKA & $-38 \%$ & $-10 \%$ & $5 \%$ & $29 \%$ & $-9 \%$ & $39 \%$ & $-9 \%$ & $-3 \%$ & $14 \%$ & $17 \%$ \\
\hline
\end{tabular}

Izvor: izračun autora i statistički podaci iz Međunarodnog monetarnog fonda (IMF DOTS) 
Obveznički prinosi: rezultati modela pokazuju snažno djelovanje šoka aktive na obvezničke prinose. Slika 5 ukazuje na snažan statistički negativan (ekonomski pozitivan) doprinos šoka aktive ESB-a od sredine 2012. do početka 2015. godine.

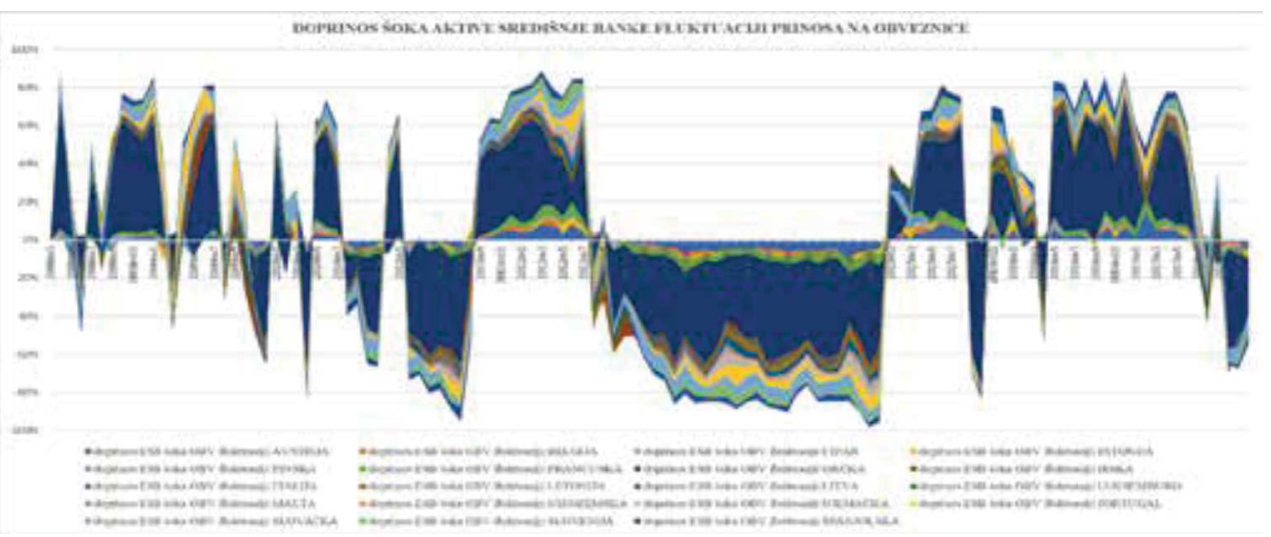

Slika 5. Doprinos šoka promjene aktive ESB-a fluktuaciji obvezničkih prinosa

Izvor: izrada autora

Napomena: rezultati modela, funkcija historijske dekompozicije, sve promatrane zemlje

Kamate na obveznice smanjivale su se kod velike većine zemalja najviše neposredno nakon perioda rasta aktive $2013 \mathrm{~m} 1$ te kroz 2015. i 2017. godinu.

Tablica 4. Godišnja promjena obvezničkih prinosa

\begin{tabular}{|c|r|r|r|r|r|r|r|r|r|r|}
\hline OBV & $2009 \mathrm{~m} 1$ & $2010 \mathrm{~m} 1$ & $2011 \mathrm{~m} 1$ & $2012 \mathrm{~m} 1$ & $2013 \mathrm{~m} 1$ & $2014 \mathrm{~m} 1$ & $2015 \mathrm{~m} 1$ & $2016 \mathrm{~m} 1$ & $2017 \mathrm{~m} 1$ & $2017 \mathrm{~m} 12$ \\
\hline AUSTRIJA & $-5 \%$ & $-6 \%$ & $-6 \%$ & $-8 \%$ & $-41 \%$ & $11 \%$ & $-75 \%$ & $43 \%$ & $-26 \%$ & $14 \%$ \\
\hline BELGIJA & $-3 \%$ & $-9 \%$ & $10 \%$ & $-1 \%$ & $-44 \%$ & $6 \%$ & $-70 \%$ & $18 \%$ & $-19 \%$ & $-17 \%$ \\
\hline CIPAR & $0 \%$ & $0 \%$ & $0 \%$ & $52 \%$ & $0 \%$ & $-14 \%$ & $0 \%$ & $-36 \%$ & $-10 \%$ & $-54 \%$ \\
\hline ESTONIJA & $11 \%$ & $2 \%$ & $8 \%$ & $10 \%$ & $-41 \%$ & $23 \%$ & $-34 \%$ & $11 \%$ & $-22 \%$ & $-25 \%$ \\
\hline FINSKA & $-7 \%$ & $-10 \%$ & $-6 \%$ & $-30 \%$ & $-24 \%$ & $14 \%$ & $-69 \%$ & $26 \%$ & $-36 \%$ & $0 \%$ \\
\hline FRANCUSKA & $-13 \%$ & $-2 \%$ & $-2 \%$ & $-8 \%$ & $-32 \%$ & $10 \%$ & $-72 \%$ & $25 \%$ & $2 \%$ & $-5 \%$ \\
\hline GRČKA & $27 \%$ & $8 \%$ & $95 \%$ & $121 \%$ & $-57 \%$ & $-26 \%$ & $16 \%$ & $-4 \%$ & $-22 \%$ & $-37 \%$ \\
\hline IRSKA & $22 \%$ & $-7 \%$ & $81 \%$ & $-12 \%$ & $-46 \%$ & $-19 \%$ & $-64 \%$ & $-14 \%$ & $-6 \%$ & $-16 \%$ \\
\hline ITALIJA & $5 \%$ & $-12 \%$ & $16 \%$ & $38 \%$ & $-36 \%$ & $-8 \%$ & $-56 \%$ & $-10 \%$ & $30 \%$ & $-10 \%$ \\
\hline LETONIJA & $11 \%$ & $2 \%$ & $8 \%$ & $10 \%$ & $-41 \%$ & $23 \%$ & $-34 \%$ & $11 \%$ & $-22 \%$ & $-25 \%$ \\
\hline LITVA & $11 \%$ & $2 \%$ & $8 \%$ & $10 \%$ & $-41 \%$ & $23 \%$ & $-34 \%$ & $11 \%$ & $-22 \%$ & $-25 \%$ \\
\hline LUKSEMBURG & $-6 \%$ & $-10 \%$ & $-12 \%$ & $-37 \%$ & $-23 \%$ & $29 \%$ & $-77 \%$ & $53 \%$ & $-40 \%$ & $33 \%$ \\
\hline MALTA & $-6 \%$ & $3 \%$ & $0 \%$ & $-5 \%$ & $-13 \%$ & $-18 \%$ & $-45 \%$ & $-26 \%$ & $-6 \%$ & $17 \%$ \\
\hline NIZOZEMSKA & $-9 \%$ & $-8 \%$ & $-7 \%$ & $-32 \%$ & $-21 \%$ & $20 \%$ & $-75 \%$ & $25 \%$ & $-26 \%$ & $-6 \%$ \\
\hline NJEMAČKA & $-24 \%$ & $6 \%$ & $-8 \%$ & $-39 \%$ & $-17 \%$ & $17 \%$ & $-78 \%$ & $10 \%$ & $-42 \%$ & $36 \%$ \\
\hline PORTUGAL & $0 \%$ & $-3 \%$ & $67 \%$ & $99 \%$ & $-55 \%$ & $-17 \%$ & $-52 \%$ & $9 \%$ & $46 \%$ & $-17 \%$ \\
\hline SLOVAČKA & $5 \%$ & $-12 \%$ & $1 \%$ & $25 \%$ & $-25 \%$ & $-36 \%$ & $-57 \%$ & $-35 \%$ & $45 \%$ & $0 \%$ \\
\hline SLOVENIJA & $7 \%$ & $-15 \%$ & $7 \%$ & $57 \%$ & $-29 \%$ & $-2 \%$ & $-63 \%$ & $-8 \%$ & $-39 \%$ & $-1 \%$ \\
\hline ŠPANJOLSKA & $-1 \%$ & $-4 \%$ & $35 \%$ & $1 \%$ & $-7 \%$ & $-25 \%$ & $-59 \%$ & $12 \%$ & $-15 \%$ & $-1 \%$ \\
\hline
\end{tabular}

Izvor: izračun autora i statistički podaci iz Međunarodnog monetarnog fonda (IMF IFS) 
Burzovna aktivnost: Dosta manjim intenzitetom u usporedbi s obveznicama, no ipak se prepoznaju utjecaji šokova aktive na burzovnu aktivnost $u$ periodima intenzivne promjene aktive ESB-a.

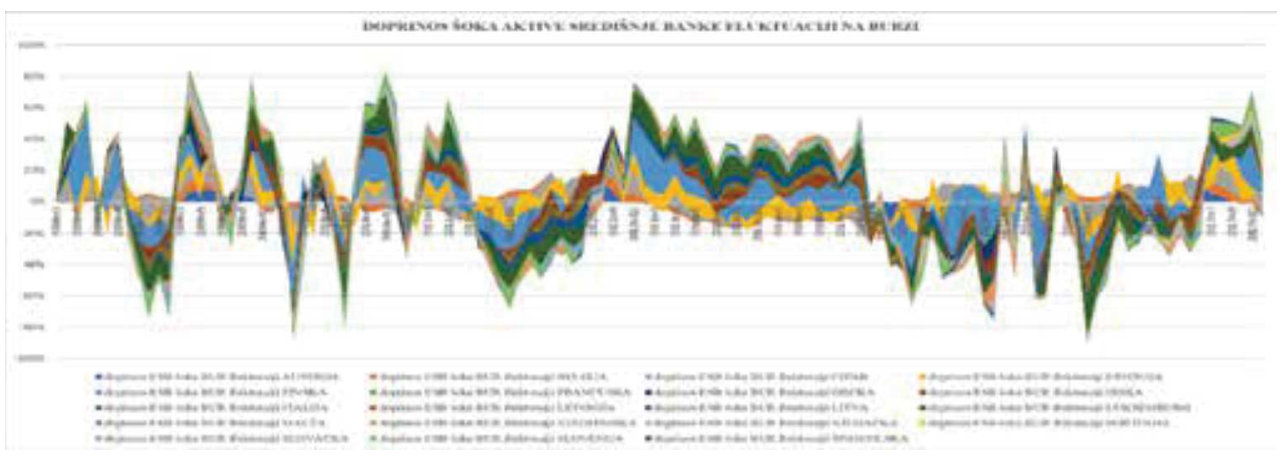

Slika 6. Doprinos šoka promjene aktive ESB-a fluktuaciji burzovne aktivnosti

Izvor: izrada autora

Napomena: rezultati modela, funkcija historijske dekompozicije, sve promatrane zemlje

Usporedba perioda intenzivne promjene aktive s burzovnom fluktuacijom rezultira zanimljivošću da 2012m1, kao referentni vremenski presjek koji je središte perioda najintenzivnijeg rasta aktive 2011m8 - 2012m8, bilježi jaku kontrakciju burzovne aktivnosti kod svih zemalja europodručja u odnosu na godinu dana prije. Tek u zadnjem kvartalu 2012. godine burzovna aktivnost uglavnom raste i oporavlja se tijekom 2013. i 2014. godine, kada je aktiva ESB-a u padu. S drugom fazom povećanja aktive od početka 2015. godine burzovna aktivnost uglavnom se intenzivira te krajem promatranog razdoblja dostiže razine 2011. godine.

Tablica 5. Godišnje promjene burzovnih indeksa

\begin{tabular}{|c|c|c|c|c|c|c|c|c|c|c|}
\hline BUR & $2009 \mathrm{ml}$ & $2010 \mathrm{ml}$ & $2011 \mathrm{~m} 1$ & $2012 \mathrm{~m} 1$ & $2013 \mathrm{~m} 1$ & $2014 \mathrm{ml}$ & $2015 \mathrm{~m} 1$ & $2016 \mathrm{ml}$ & $2017 \mathrm{~m} 1$ & $2017 \mathrm{~m} 12$ \\
\hline AUSTRIJA & $-62 \%$ & $54 \%$ & $20 \%$ & $-31 \%$ & $17 \%$ & $5 \%$ & $-20 \%$ & $2 \%$ & $25 \%$ & $31 \%$ \\
\hline BELGIJA & $-49 \%$ & $32 \%$ & $5 \%$ & $-16 \%$ & $14 \%$ & $15 \%$ & $22 \%$ & $-1 \%$ & $1 \%$ & $0 \%$ \\
\hline CIPAR & $\mathrm{n} / \mathrm{a}$ & $\mathrm{n} / \mathrm{a}$ & $\mathrm{n} / \mathrm{a}$ & $\mathrm{n} / \mathrm{a}$ & $-73 \%$ & $-9 \%$ & $-37 \%$ & $-13 \%$ & $-6 \%$ & $-6 \%$ \\
\hline ESTONIJA & $-53 \%$ & $97 \%$ & $27 \%$ & $-27 \%$ & $41 \%$ & $8 \%$ & $-2 \%$ & $8 \%$ & $18 \%$ & $0 \%$ \\
\hline FINSKA & $-53 \%$ & $19 \%$ & $19 \%$ & $-30 \%$ & $8 \%$ & $26 \%$ & $6 \%$ & $11 \%$ & $4 \%$ & $6 \%$ \\
\hline FRANCUSKA & $-39 \%$ & $26 \%$ & $7 \%$ & $-18 \%$ & $13 \%$ & $12 \%$ & $11 \%$ & $-4 \%$ & $2 \%$ & $0 \%$ \\
\hline GRČKA & $-60 \%$ & $13 \%$ & $-29 \%$ & $-54 \%$ & $-2 \%$ & $16 \%$ & $-44 \%$ & $-29 \%$ & $7 \%$ & $27 \%$ \\
\hline IRSKA & $-69 \%$ & $18 \%$ & $-13 \%$ & $10 \%$ & $10 \%$ & $55 \%$ & $23 \%$ & $16 \%$ & $-9 \%$ & $21 \%$ \\
\hline ITALIJA & $-48 \%$ & $22 \%$ & $1 \%$ & $-28 \%$ & $10 \%$ & $11 \%$ & $6 \%$ & $-9 \%$ & $0 \%$ & $18 \%$ \\
\hline LETONIJA & $-57 \%$ & $36 \%$ & $30 \%$ & $-10 \%$ & $5 \%$ & $21 \%$ & $-14 \%$ & $48 \%$ & $23 \%$ & $32 \%$ \\
\hline LITVA & $-58 \%$ & $65 \%$ & $29 \%$ & $-24 \%$ & $20 \%$ & $21 \%$ & $2 \%$ & $5 \%$ & $15 \%$ & $16 \%$ \\
\hline LUKSEMBURG & $-63 \%$ & $31 \%$ & $4 \%$ & $-25 \%$ & $9 \%$ & $-4 \%$ & $-2 \%$ & $-9 \%$ & $33 \%$ & $-14 \%$ \\
\hline MALTA & $\mathrm{n} / \mathrm{a}$ & $\mathrm{n} / \mathrm{a}$ & $\mathrm{n} / \mathrm{a}$ & $\mathrm{n} / \mathrm{a}$ & $\mathrm{n} / \mathrm{a}$ & $\mathrm{n} / \mathrm{a}$ & $\mathrm{n} / \mathrm{a}$ & $\mathrm{n} / \mathrm{a}$ & $5 \%$ & $-4 \%$ \\
\hline NIZOZEMSKA & $-44 \%$ & $32 \%$ & $10 \%$ & $-12 \%$ & $11 \%$ & $9 \%$ & $16 \%$ & $-4 \%$ & $1 \%$ & $0 \%$ \\
\hline NJEMAČKA & $-37 \%$ & $29 \%$ & $26 \%$ & $-9 \%$ & $20 \%$ & $20 \%$ & $15 \%$ & $-8 \%$ & $18 \%$ & $12 \%$ \\
\hline PORTUGAL & $\mathrm{n} / \mathrm{a}$ & $\mathrm{n} / \mathrm{a}$ & $\mathrm{n} / \mathrm{a}$ & $-32 \%$ & $16 \%$ & $8 \%$ & $-23 \%$ & $-2 \%$ & $-12 \%$ & $20 \%$ \\
\hline SLOVAČKA & $\mathrm{n} / \mathrm{a}$ & $\mathrm{n} / \mathrm{a}$ & $\mathrm{n} / \mathrm{a}$ & $\mathrm{n} / \mathrm{a}$ & $-10 \%$ & $5 \%$ & $16 \%$ & $36 \%$ & $-1 \%$ & $6 \%$ \\
\hline SLOVENIJA & $-60 \%$ & $11 \%$ & $-16 \%$ & $-29 \%$ & $7 \%$ & $10 \%$ & $13 \%$ & $-13 \%$ & $8 \%$ & $9 \%$ \\
\hline ŠPANJOLSKA & $-36 \%$ & $30 \%$ & $-1 \%$ & $-21 \%$ & $-2 \%$ & $19 \%$ & $5 \%$ & $-15 \%$ & $-1 \%$ & $0 \%$ \\
\hline
\end{tabular}

Izvor: izračun autora i podaci iz Bloomberga 
B. Franović: Učinkovitost nekonvencionalnih mjera monetarne politike Europske središnje banke...

Kreditna aktivnost banaka: Kod ove varijable rezultati modela ne pokazuju tako jasnu vezu šoka aktive ESB-a s kreditnom aktivnošću banaka koja bi se, kao kod ostalih varijabli modela, poklapala s periodima smanjenja i povećanja aktive.

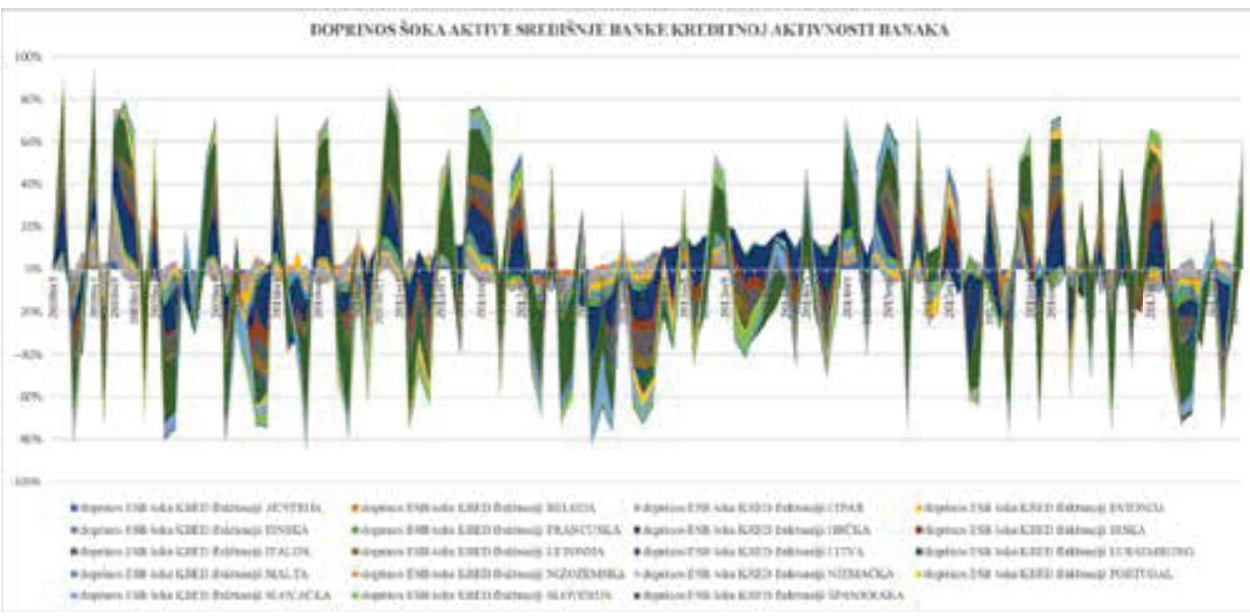

Slika 7. Doprinos šoka promjene aktive ESB-a fluktuaciji kreditne aktivnosti banaka

Izvor: izrada autora

Napomena: rezultati modela, funkcija historijske dekompozicije, sve promatrane zemlje

Tablica 6. Godišnja promjena kreditne aktivnosti banaka

\begin{tabular}{|c|r|r|r|r|r|r|r|r|r|r|}
\hline KRED & $2009 \mathrm{~m} 1$ & $2010 \mathrm{~m} 1$ & $2011 \mathrm{~m} 1$ & $2012 \mathrm{~m} 1$ & $2013 \mathrm{~m} 1$ & $2014 \mathrm{~m} 1$ & $2015 \mathrm{~m} 1$ & $2016 \mathrm{~m} 1$ & $2017 \mathrm{~m} 1$ & $2017 \mathrm{~m} 12$ \\
\hline AUSTRIJA & $7 \%$ & $0 \%$ & $2 \%$ & $2 \%$ & $0 \%$ & $0 \%$ & $0 \%$ & $0 \%$ & $1 \%$ & $3 \%$ \\
\hline BELGIJA & $7 \%$ & $1 \%$ & $4 \%$ & $3 \%$ & $2 \%$ & $3 \%$ & $3 \%$ & $4 \%$ & $6 \%$ & $4 \%$ \\
\hline CIPAR & $28 \%$ & $5 \%$ & $7 \%$ & $7 \%$ & $2 \%$ & $-7 \%$ & $0 \%$ & $-4 \%$ & $-6 \%$ & $-5 \%$ \\
\hline ESTONIJA & $6 \%$ & $-5 \%$ & $-6 \%$ & $-4 \%$ & $0 \%$ & $1 \%$ & $5 \%$ & $9 \%$ & $10 \%$ & $1 \%$ \\
\hline FINSKA & $9 \%$ & $1 \%$ & $5 \%$ & $7 \%$ & $4 \%$ & $4 \%$ & $3 \%$ & $3 \%$ & $3 \%$ & $3 \%$ \\
\hline FRANCUSKA & $6 \%$ & $0 \%$ & $5 \%$ & $4 \%$ & $1 \%$ & $0 \%$ & $1 \%$ & $3 \%$ & $5 \%$ & $4 \%$ \\
\hline GRČKA & $8 \%$ & $-4 \%$ & $20 \%$ & $-3 \%$ & $-9 \%$ & $-4 \%$ & $-2 \%$ & $-5 \%$ & $-5 \%$ & $-5 \%$ \\
\hline IRSKA & $8 \%$ & $-9 \%$ & $-11 \%$ & $-3 \%$ & $-6 \%$ & $-8 \%$ & $-17 \%$ & $-11 \%$ & $-8 \%$ & $-3 \%$ \\
\hline ITALIJA & $6 \%$ & $1 \%$ & $16 \%$ & $2 \%$ & $-1 \%$ & $-3 \%$ & $-2 \%$ & $0 \%$ & $-2 \%$ & $-1 \%$ \\
\hline LETONIJA & $\mathrm{n} / \mathrm{a}$ & $\mathrm{n} / \mathrm{a}$ & $\mathrm{n} / \mathrm{a}$ & $-8 \%$ & $-10 \%$ & $-9 \%$ & $-4 \%$ & $-2 \%$ & $4 \%$ & $-3 \%$ \\
\hline LITVA & $16 \%$ & $-8 \%$ & $-6 \%$ & $-7 \%$ & $0 \%$ & $-4 \%$ & $-1 \%$ & $6 \%$ & $9 \%$ & $4 \%$ \\
\hline LUKSEMBURG & $3 \%$ & $-3 \%$ & $6 \%$ & $1 \%$ & $1 \%$ & $1 \%$ & $12 \%$ & $5 \%$ & $4 \%$ & $8 \%$ \\
\hline MALTA & $14 \%$ & $7 \%$ & $5 \%$ & $4 \%$ & $2 \%$ & $-1 \%$ & $7 \%$ & $1 \%$ & $2 \%$ & $3 \%$ \\
\hline NIZOZEMSKA & $11 \%$ & $6 \%$ & $-4 \%$ & $1 \%$ & $1 \%$ & $-4 \%$ & $0 \%$ & $-3 \%$ & $3 \%$ & $-2 \%$ \\
\hline NJEMAČKA & $6 \%$ & $0 \%$ & $0 \%$ & $3 \%$ & $-1 \%$ & $-4 \%$ & $2 \%$ & $3 \%$ & $3 \%$ & $4 \%$ \\
\hline PORTUGAL & $10 \%$ & $5 \%$ & $6 \%$ & $-1 \%$ & $-8 \%$ & $-5 \%$ & $-7 \%$ & $-4 \%$ & $-4 \%$ & $-3 \%$ \\
\hline SLOVAČKA & $13 \%$ & $1 \%$ & $5 \%$ & $8 \%$ & $3 \%$ & $5 \%$ & $6 \%$ & $10 \%$ & $11 \%$ & $9 \%$ \\
\hline SLOVENIJA & $16 \%$ & $2 \%$ & $2 \%$ & $-3 \%$ & $-6 \%$ & $-17 \%$ & $-13 \%$ & $-7 \%$ & $-2 \%$ & $4 \%$ \\
\hline ŠPANJOLSKA & $11 \%$ & $-1 \%$ & $1 \%$ & $-4 \%$ & $-11 \%$ & $-10 \%$ & $-6 \%$ & $-5 \%$ & $-4 \%$ & $-2 \%$ \\
\hline
\end{tabular}

Izvor: izračun autora i statistički podaci iz baze European Central Bank Statistical Data Warehouse (SDW) 
U nastavku su predstavljeni rezultati 19 provedenih modela, to jest za svaku članicu europodručja. Za svaku zemlju komentira se jačina doprinosa šoka aktive fluktuaciji varijabli u usporedbi s ostalim članicama europodručja. Doprinosi se kvalificiraju kao relativno: veći, umjeren i manji. To je prikazano slikom 8.

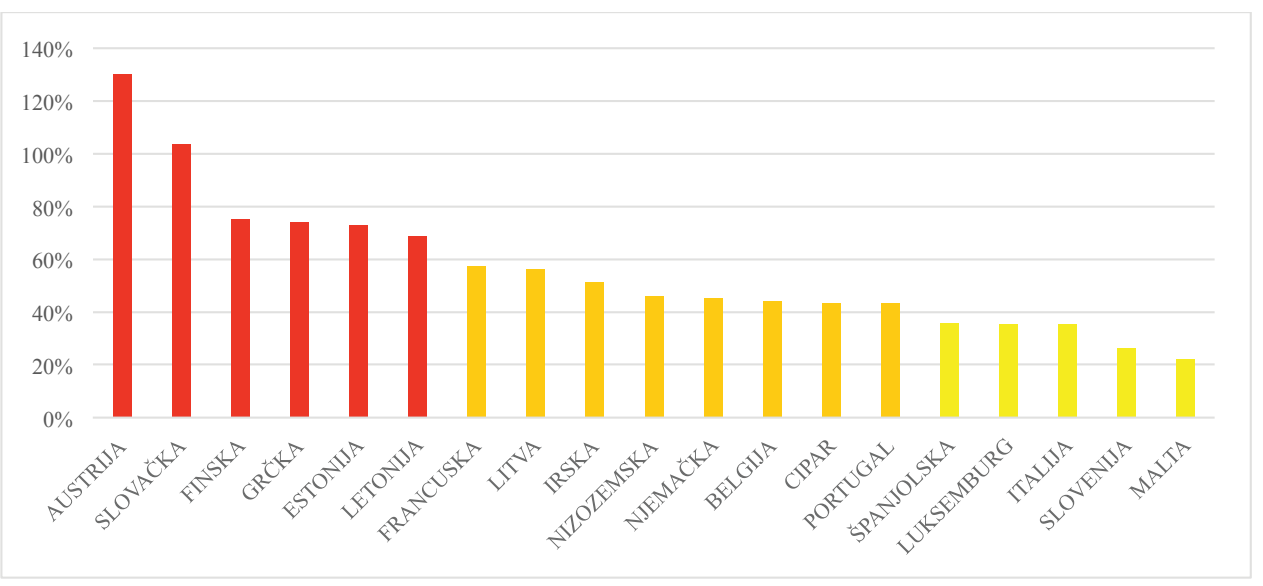

Slika 8. Usporedba jačine doprinosa šoka aktive ESB-a fluktuaciji varijabli zemalja EMU-a

Izvor: izrada autora, rezultati modela - rezultati funkcije historijske dekompozicije

Za svaku zemlju izlaže se doprinos šoka promjene aktive ESB-a fluktuaciji varijabli industrijske proizvodnje (IND), nezaposlenosti (NEZ), kredita banaka (KRED), obvezničkih prinosa (OBV), burzovne aktivnosti (BUR) i izvoza (IZVOZ), dobiven na osnovi rezultata funkcije historijske dekompozicije.

Također, na osnovu istih rezultata prikazuje se usporedba relativnog značaja transmisijskih kanala - kanala bankovnog kreditiranja, kanala uravnoteženja portfelja, kanala cijena (dionica) imovine i kanala izvoza.

S ciljem usporedbe i rangiranja jačine doprinosa pojedinih šokova fluktuaciji varijabli modela te značaja pojedinih transmisijskih kanala u promatranom periodu, rezultati funkcije historijske dekompozicije uspoređeni su preko medijana u apsolutnom iznosu.

Dodatno se za svaku zemlju predstavljaju rezultati funkcije impulsnog odziva 6 varijabli (IND, NEZ, KRED, OBV, BUR i IZVOZ) na šok promjene aktive ESB-a. 


\section{1) Austrija:}
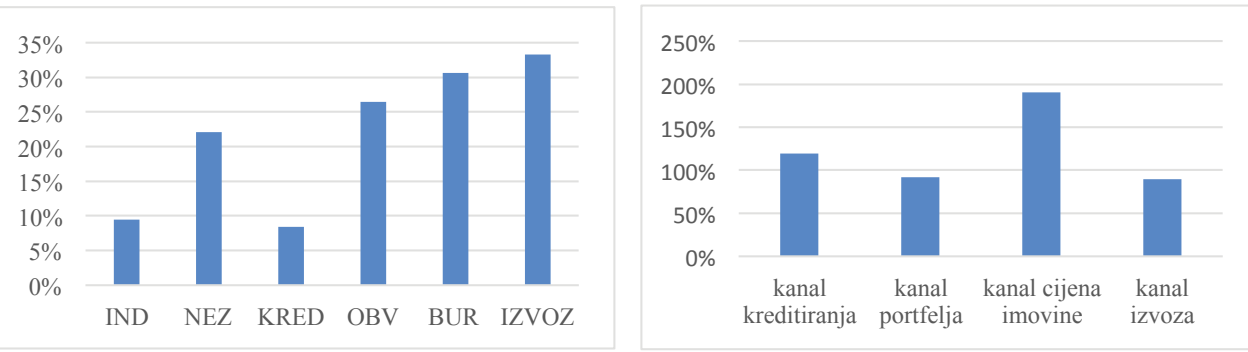

Slika 9. Austrija - doprinos šoka aktive ESB-a fluktuaciji varijabli i transmisijski kanali

Izvor: izrada autora, rezultati modela - rezultati funkcije historijske dekompozicije

Slika 8 ukazuje na relativno veći doprinos šoka promjene aktive ESB-a fluktuaciji varijabli. Doprinosi fluktuaciji varijabli rangirani po jačini su: IZVOZ, BUR, OBV, NEZ, IND i KRED. Najveći pozitivni doprinos vidljiv je od kraja 2011. do početka 2015. godine, s posustajanjem u periodu smanjenja aktive od sredine 2013. do sredine 2014. godine.

Transmisijski kanali po važnosti: kanal cijena (dionica) imovine, kanal bankovnog kreditiranja, kanal uravnoteženja portfelja pa kanal izvoza.

Rezultati funkcije impulsnog odziva na šok promjene aktive ESB-a (slika 10) ukazuju na trenutačni odziv varijabli: IND i KRED (s vrhom odziva u 2. mjesecu od trenutka nastanka šoka), BUR i IZVOZ (s vrhom u 3. mjesecu) te OBV (s vrhom u 4. mjesecu). Varijabla NEZ vrh odziva dostiže u 4. mjesecu i jedina reagira s kašnjenjem od 2 mjeseca od nastanka šoka.

Rezultati modela i stvarno kretanje varijabli ukazuju na pozitivan utjecaj paketa kupnji imovine, naročito oko prvog perioda intenzivnog povećanja aktive ESB-a (2011m8 2012m8). 

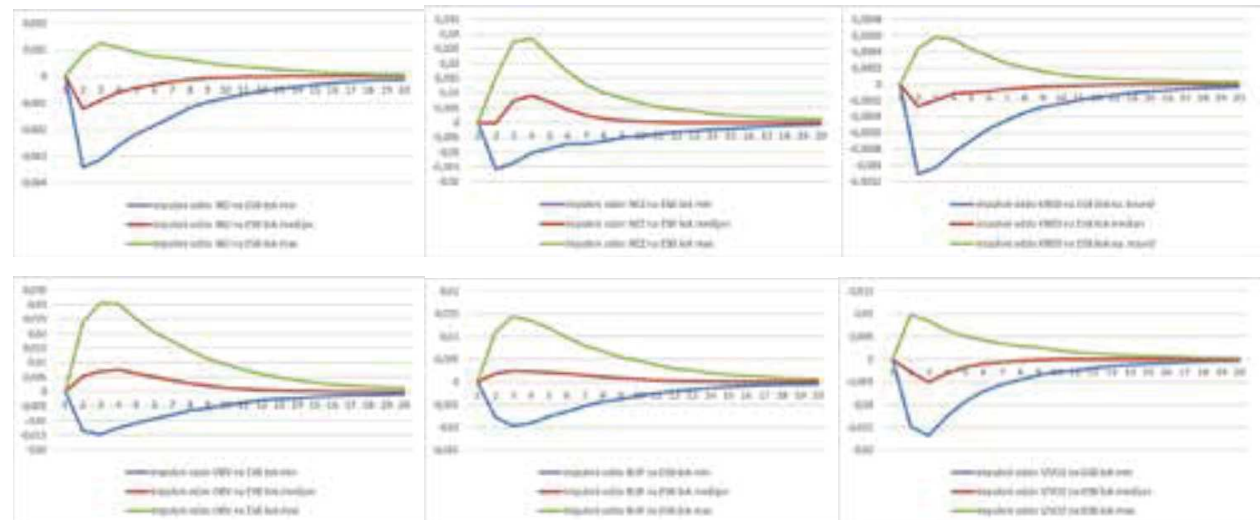

Slika 10. Funkcije impulsnog odziva na šok promjene aktive ESB-a: Austrija

Izvor: izrada autora, rezultati modela

\section{2) Belgija:}
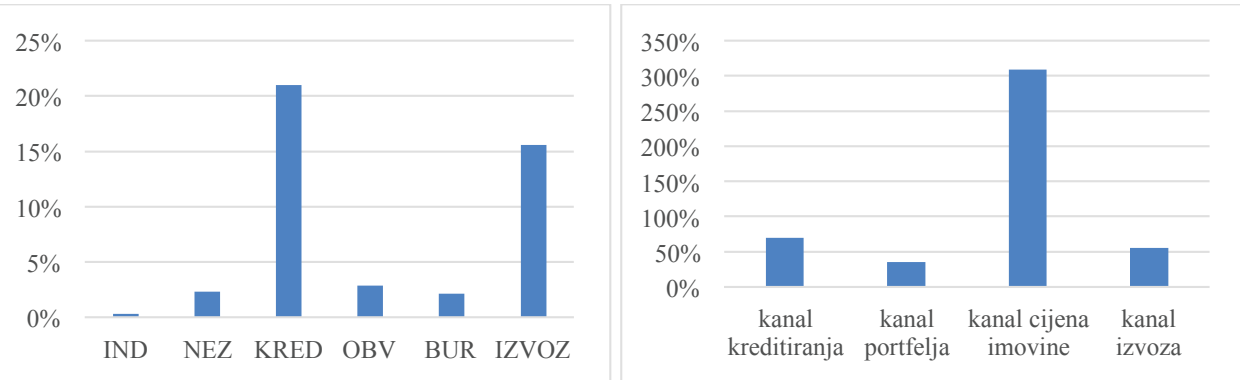

Slika 11. Belgija - doprinos šoka aktive ESB-a fluktuaciji varijabli i transmisijski kanali

Izvor: izrada autora, rezultati modela - rezultati funkcije historijske dekompozicije

Rezultati funkcije historijske dekompozicije na slici 8 ukazuju na relativno umjeren doprinos šoka promjene aktive ESB-a fluktuaciji varijabli modela. Doprinosi rangirani po jačini su: KRED, IZVOZ, OBV, BUR, NEZ i IND. Negativni statistički doprinos šoka primjetan je tijekom perioda prvog intenzivnog povećanja aktive ESB-a (2011m8 - 2012m8), a pozitivan i znatno dulji nakon njega sve do kraja 2014. godine. Varijable nezaposlenosti i obvezničkih prinosa najviše su padale upravo tijekom i oko dvaju perioda intenzivnog povećanja aktive ESB-a. Izvoz je na većim razinama oko prvog intenzivnog razdoblja povećanja imovine u odnosu na drugi nakon 2015. godine. Kreditna aktivnost u stalnom je porastu tijekom perioda promatranja. Burzovna aktivnost pada krajem 2010. godine te ponovno raste s prvim intenzivnim periodom kupnji.

Transmisijski kanali po važnosti: kanal cijena (dionica) imovine, kanal bankovnog kreditiranja, kanal izvoza pa kanal uravnoteženja portfelja. 
Slika 12 pokazuje trenutačni odziv svih varijabli modela $\mathrm{s}$ vrhom odziva: IND i KRED (u 2. mjesecu), BUR, IZVOZ i NEZ (u 3. mjesecu) i OBV (u 5. mjesecu).
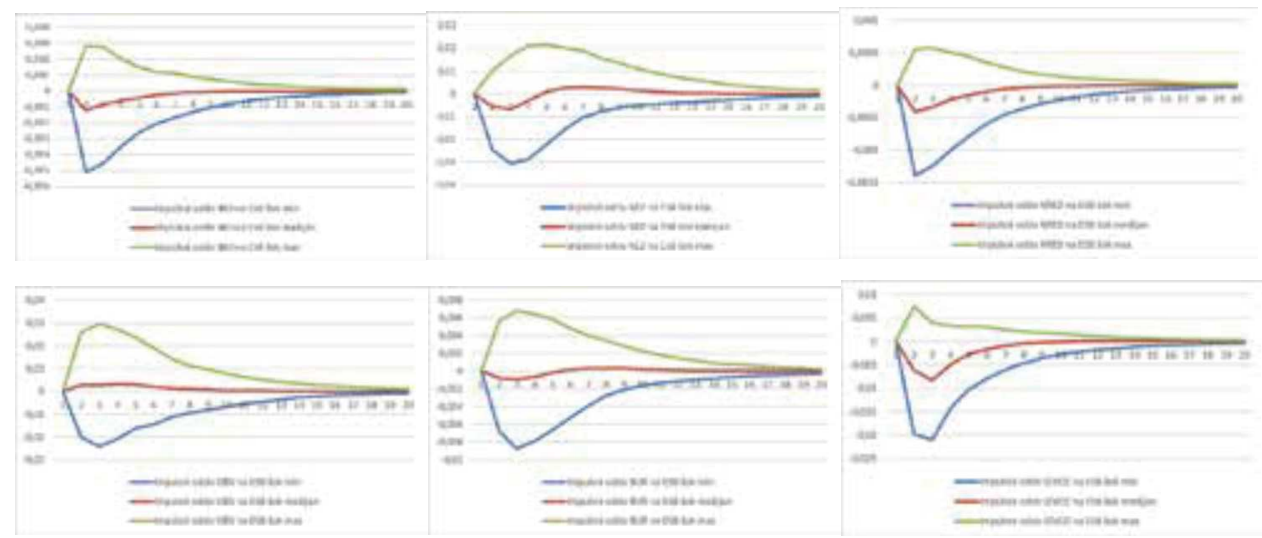

Slika 12. Funkcije impulsnog odziva na šok promjene aktive ESB-a: Belgija

Izvor: izrada autora, rezultati modela

\section{3) Cipar:}
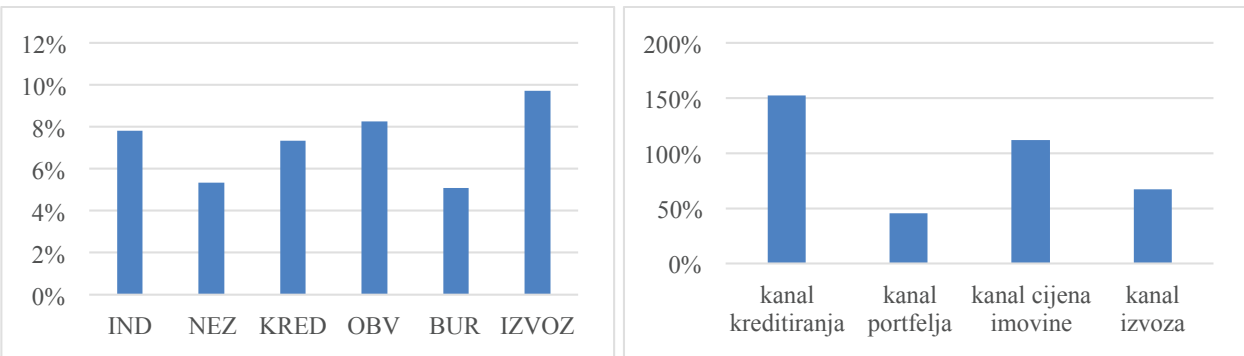

Slika 13. Cipar - doprinos šoka aktive ESB-a fluktuaciji varijabli i transmisijski kanali

Izvor: izrada autora, rezultati modela - rezultati funkcije historijske dekompozicije

Rezultati funkcije historijske dekompozicije na slici 8 ukazuju na relativno umjeren doprinos šoka promjene aktive ESB-a fluktuaciji varijabli modela. Doprinosi rangirani po jačini su: IZVOZ, OBV, IND, KRED, NEZ i BUR.

Rezultati modela sugeriraju da je kanal bankovnog kreditiranja dominantan u fluktuaciji nezaposlenosti i industrijske proizvodnje. Vidljiv je njegov najveći doprinos kako u prvotnim periodima izrazitog pogoršanja, tako i u oporavku krajem promatranog razdoblja. Transmisijski kanali po važnosti: kanal bankovnog kreditiranja, kanal cijena (dionica) imovine, kanal izvoza pa kanal uravnoteženja portfelja.

Rezultati funkcije impulsnog odziva na identificirani šok nekonvencionalne monetarne politike, na slici 14, pokazuju trenutačni odziv svih varijabli s vrhom odziva: IND, OBV, BUR i KRED (u 2. mjesecu) te IZVOZ i NEZ (u 3. mjesecu). 

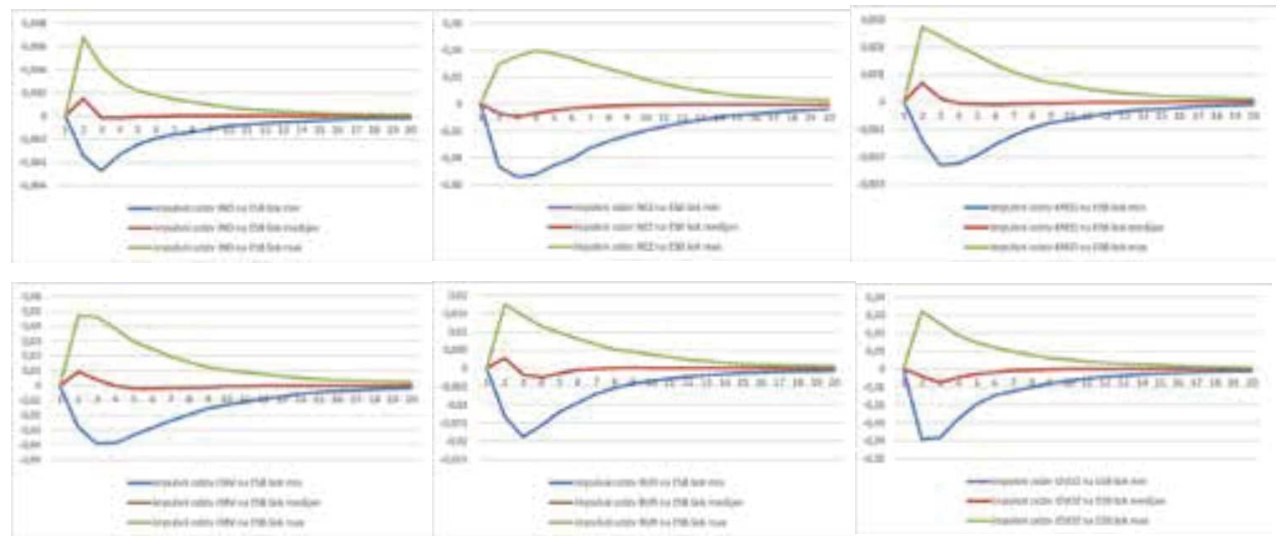

Slika 14. Funkcije impulsnog odziva na šok promjene aktive ESB-a: Cipar

Izvor: izrada autora, rezultati modela

\section{4) Estonija:}
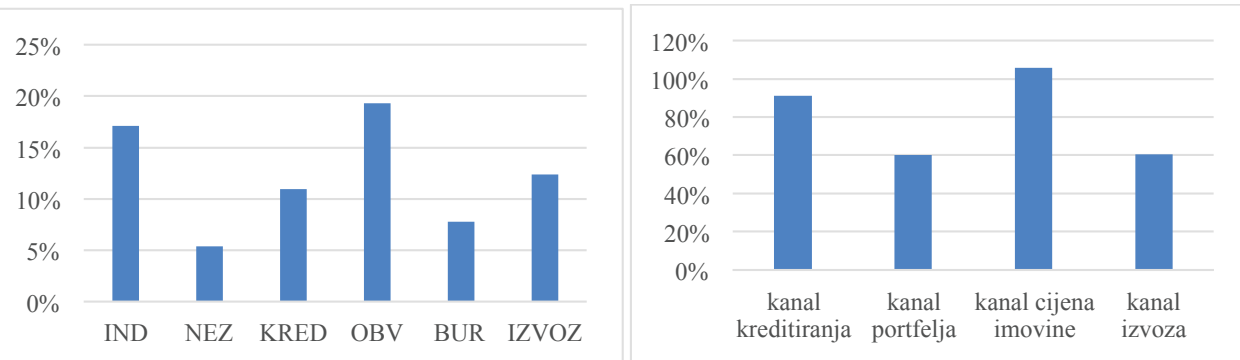

Slika 15. Estonija- doprinos šoka aktive ESB-a fluktuaciji varijabli i transmisijski kanali

Izvor: izrada autora, rezultati modela - rezultati funkcije historijske dekompozicije

Rezultati funkcije historijske dekompozicije na slici 8 ukazuju na relativno veći doprinos šoka promjene aktive ESB-a fluktuaciji varijabli modela.

Na slici 15 vidljiv je poredak doprinosa po jačini: OBV, IND, IZVOZ, KRED, BUR i NEZ. Šok aktive ESB-a kod svih varijabli (izuzev kreditne aktivnosti, gdje je mješovit) daje snažnu kontribuciju u periodu prvog porasta aktive te između zadnjeg kvartala 2012. do konca 2014. godine. Od kraja 2008. do kraja 2012. godine dominantan je kanal bankovnog kreditiranja s pozitivnim doprinosom industrijskoj proizvodnji i nezaposlenosti i opet od 2015. godine, ali u obrnutom smjeru. Primjetan je i snažan doprinos kanala izvoza fluktuaciji industrijske proizvodnje i nezaposlenosti. Transmisijski kanali po važnosti: kanal cijena (dionica) imovine, kanal bankovnog kreditiranja, kanal izvoza pa kanal uravnoteženja portfelja.

Na slici 16 vidljiv je trenutačni odziv svih varijabli s vrhom odziva: IND, BUR i KRED (u 2. mjesecu) te IZVOZ i NEZ (u 3. / 4. mjesecu). OBV reagira tek u 2. s vrhom u 3. mjesecu. 

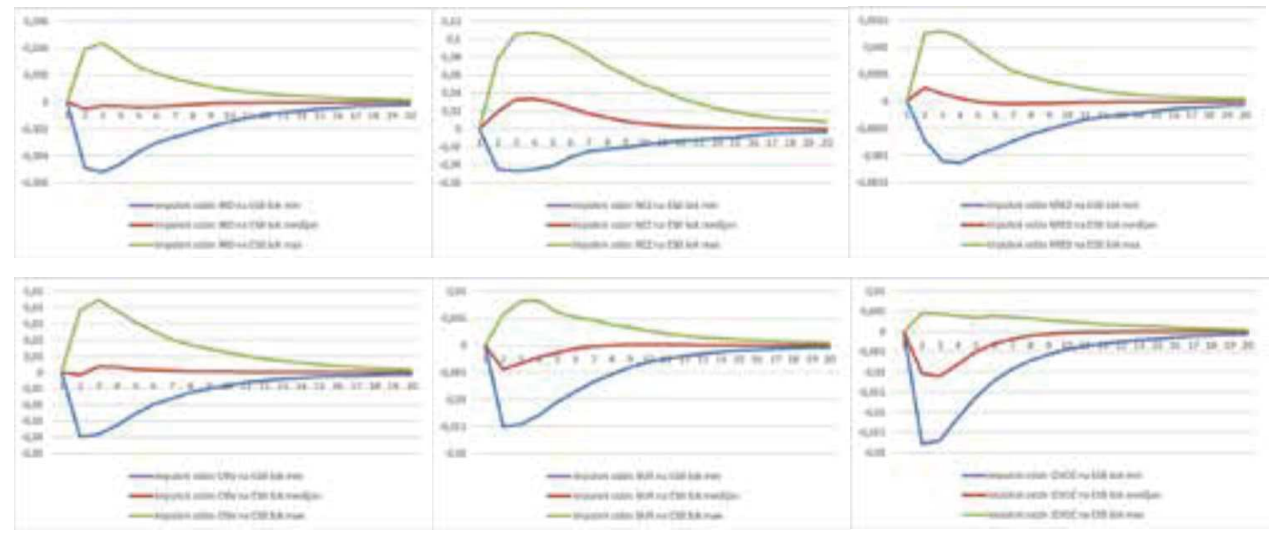

Slika 16. Funkcije impulsnog odziva na šok promjene aktive ESB-a: Estonija

Izvor: izrada autora, rezultati modela

\section{5) Finska:}
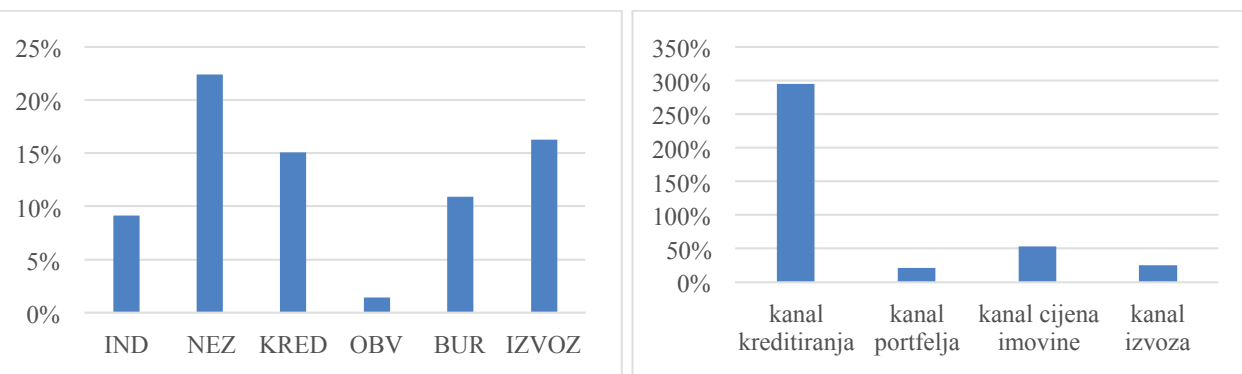

Slika 17. Finska - doprinos šoka aktive ESB-a fluktuaciji varijabli i transmisijski kanali

Izvor: izrada autora, rezultati modela - rezultati funkcije historijske dekompozicije

Slika 8 ukazuje na relativno veći doprinos šoka promjene aktive ESB-a fluktuaciji varijabli. i OBV.

Na slici 17 vidljiv je poredak doprinosa po jačini: NEZ, IZVOZ, KRED, BUR, IND

Kod svih varijabli modela, osim kreditne aktivnosti, evidentan je jak učinak šoka aktive ESB-a od sredine 2011. godine pa nadalje. Na stopu nezaposlenosti, osim šoka aktive ESB-a, djeluje i šok kreditne aktivnosti kao dominantni te obveznički šok. Na industrijsku proizvodnju pretežit utjecaj ima kreditni, zatim šok aktive pa slijedi burzovni šok. Također, vidljiv je i doprinos šoka bankovnog kreditiranja s pozitivnim učincima na realne varijable modela prema kraju promatranog perioda jer se tada osjetno povećava kreditiranje putem banaka.

Transmisijski kanali po važnosti: kanal bankovnog kreditiranja, kanal cijena (dionica) imovine, kanal izvoza pa kanal uravnoteženja portfelja. 
Na slici 18 vidljiv je trenutačni odziv svih varijabli s vrhom odziva: IZVOZ, BUR i KRED (u 2. mjesecu) te IND i OBV (u 3. mjesecu). NEZ reagira tek u 2. s vrhom u 7. mjesecu.
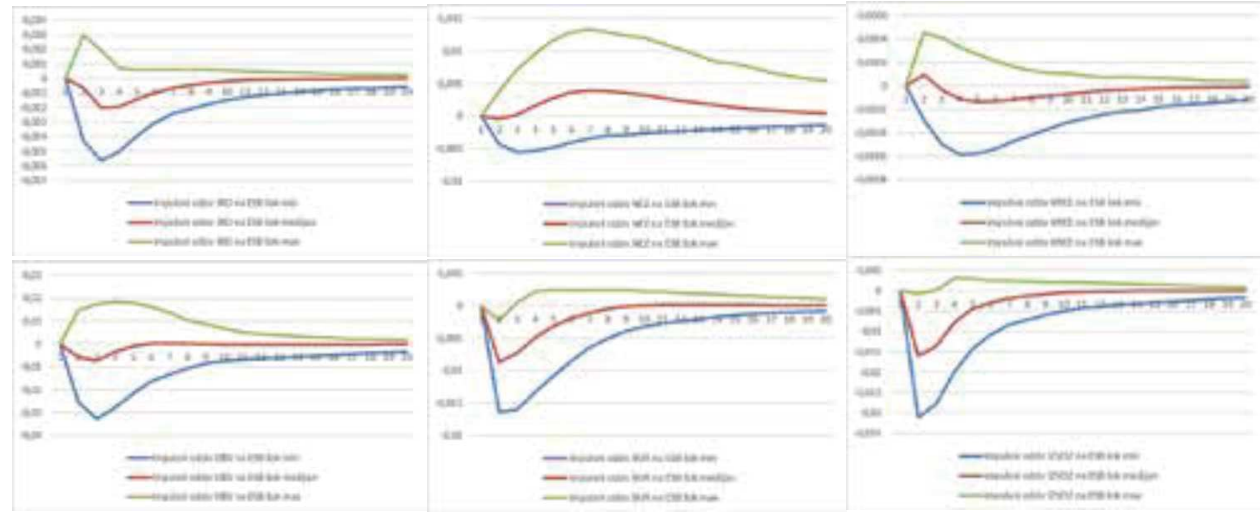

Slika 18. Funkcije impulsnog odziva na šok promjene aktive ESB-a: Finska

Izvor: izrada autora, rezultati modela

\section{6) Francuska:}
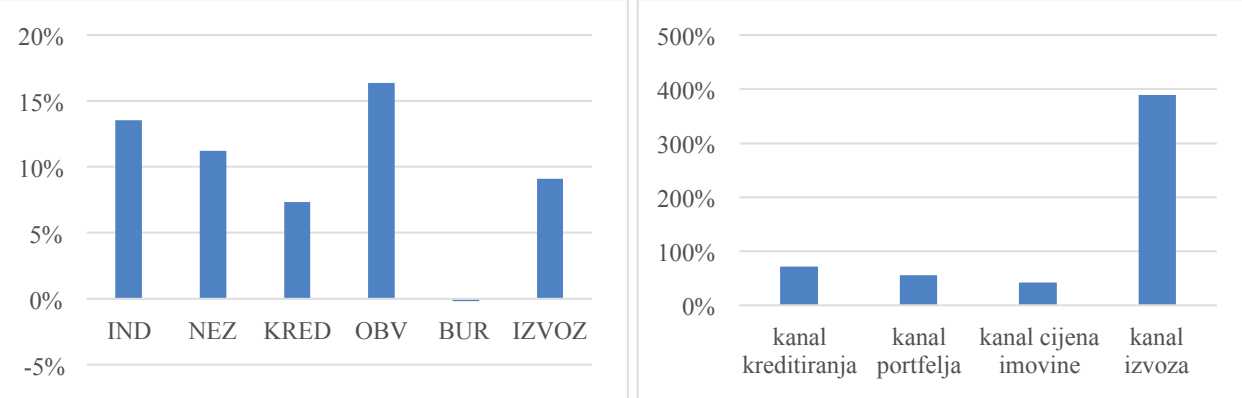

Slika 19. Francuska - doprinos šoka aktive ESB-a fluktuaciji varijabli i transmisijski kanali

Izvor: izrada autora, rezultati modela - rezultati funkcije historijske dekompozicije

Slika 8 ukazuje na relativno umjeren doprinos šoka promjene aktive ESB-a fluktuaciji varijabli. i BUR.

Na slici 19 vidljiv je poredak doprinosa po jačini: OBV, IND, NEZ, IZVOZ, KRED

Rezultati ukazuju na jak utjecaj šoka aktive ESB-a na industrijsku proizvodnju, obvezničke prinose i izvoz u periodu od sredine 2011. godine do kraja promatranog razdoblja. Osim šoka izvoza, primjetan je i doprinos šoka kreditiranja banaka te obvezničkih prinosa. Iako rezultat sugerira jaki doprinos, on nije vidljiv kroz povećanje industrijske proizvodnje, nego kroz održavanje na stabilnoj razini koja je ipak ispod one iz 2008. godine. Učinak 
nije vidljiv na stopi nezaposlenosti jer ona raste velikim dijelom promatranog razdoblja i prelazi $10 \%$, a tek koncem razdoblja počinje padati. Transmisijski kanali po važnosti: kanal izvoza, kanal bankovnog kreditiranja, kanal uravnoteženja portfelja pa kanal cijena (dionica) imovine.

Na slici 20 vidljiv je trenutačni odziv svih varijabli s vrhom odziva: IND, NEZ i KRED (u 2. mjesecu) te IZVOZ i OBV (u 4. mjesecu). NEZ reagira tek u 2. s vrhom u 4. mjesecu.
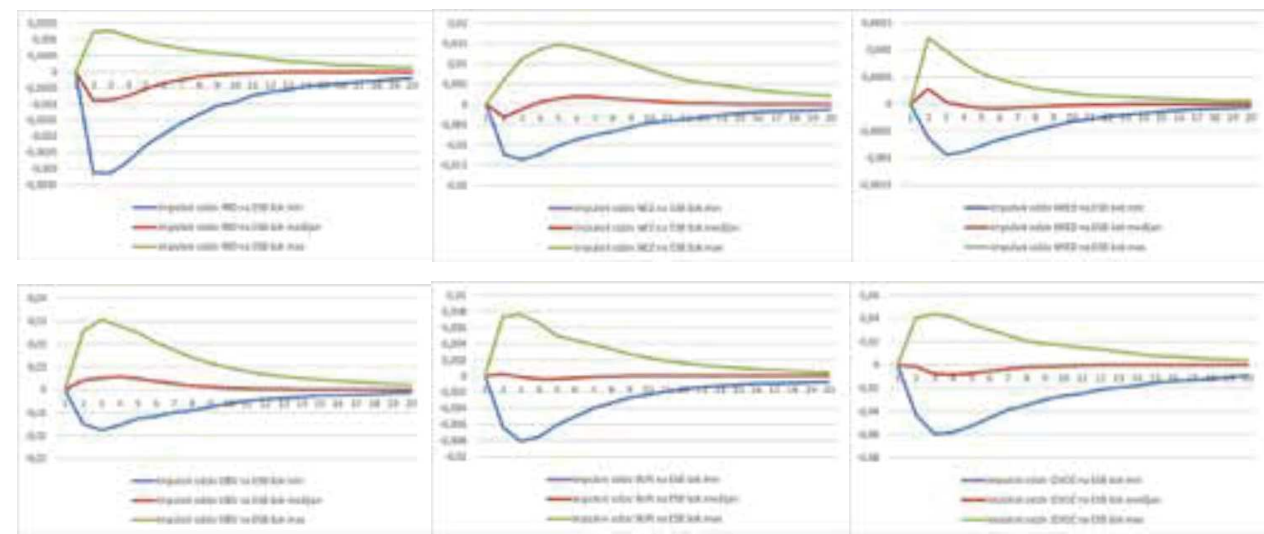

Slika 20. Funkcije impulsnog odziva na šok aktive ESB-a: Francuska

Izvor: izrada autora, rezultati modela

\section{7) Grčka:}
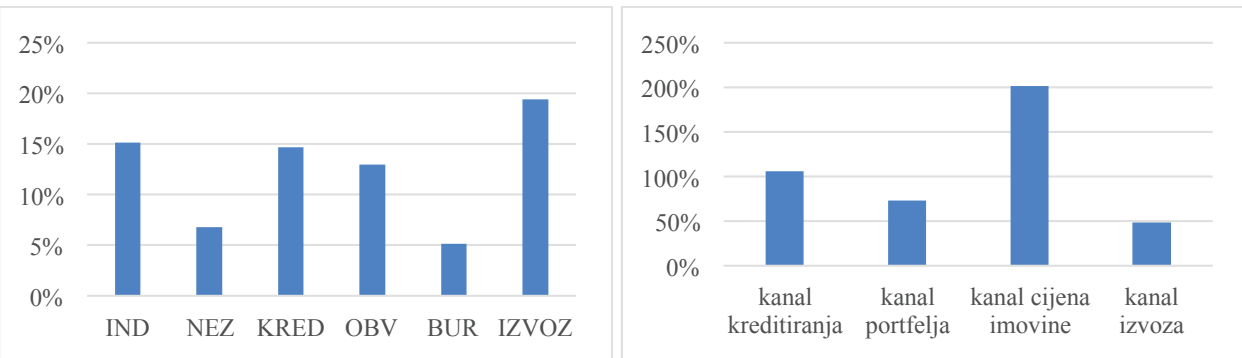

Slika 21. Grčka - doprinos šoka aktive ESB-a fluktuaciji varijabli i transmisijski kanali

Izvor: izrada autora, rezultati modela - rezultati funkcije historijske dekompozicije

Relativno veći doprinos šoka promjene aktive ESB-a fluktuaciji varijabli sugerira slika 8.

Na slici 21 vidljiv je poredak doprinosa po jačini: IZVOZ, IND, KRED, OBV, NEZ i BUR.

Rezultat modela pokazuje jaki utjecaj šoka aktive ESB-a na blago opadanje nezaposlenosti koja je s početnih $7 \%$ dostigla $27 \%$ krajem 2012. godine pa se iza toga spustila 
na $20 \%$ koncem razdoblja. Šok ESB-a djelovao je i na financijske varijable, obvezničke prinose i burzovnu aktivnost. Osim šoka aktive ESB-a primjetan i utjecaj obvezničkog šoka. Zbog ekstremnog stanja državnih financija i uspostavljenih programa monitoringa i restrukturiranja teško je tražiti indicije o vezi fluktuacija varijabli sa šokom aktive.

Transmisijski kanali po važnosti: kanal cijena (dionica) imovine, kanal bankovnog kreditiranja, kanal uravnoteženja portfelja pa kanal izvoza.

Na slici 22 vidljiv je trenutačni odziv svih varijabli s vrhom odziva: IND, NEZ, KRED, IZVOZ i BUR (u 2. mjesecu) te OBV (u 3. mjesecu).
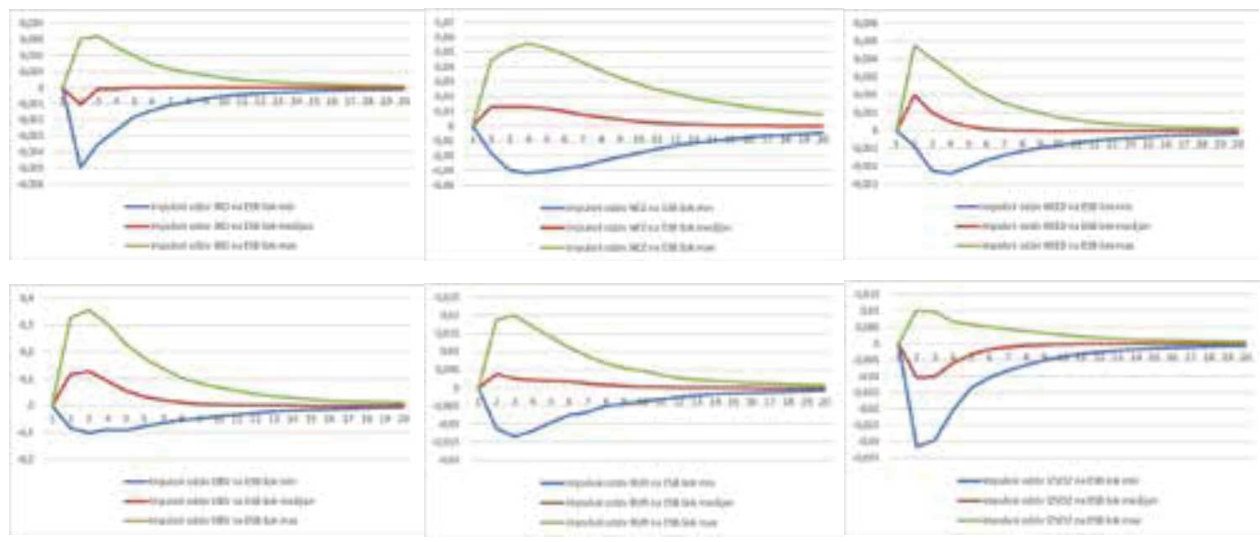

Slika 22. Funkcije impulsnog odziva na šok aktive ESB-a: Grčka

Izvor: izrada autora, rezultati modela

\section{8) Irska:}
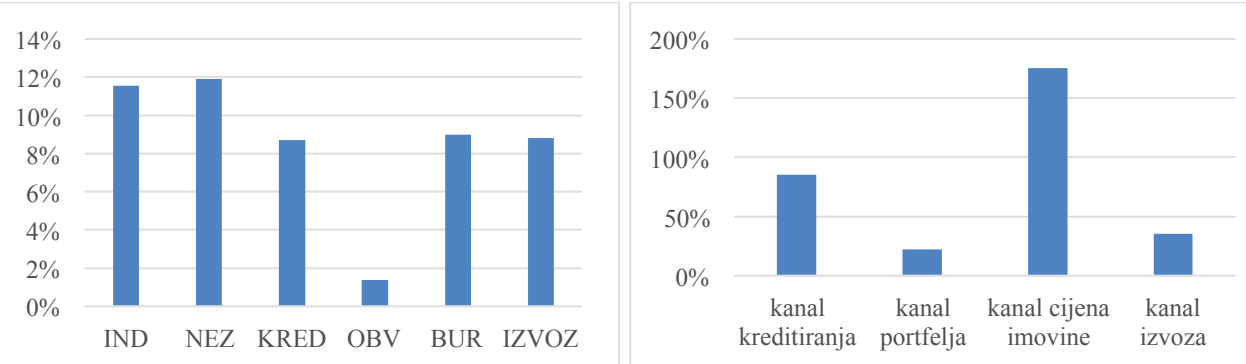

Slika 23. Irska - doprinos šoka aktive ESB-a fluktuaciji varijabli i transmisijski kanali

Izvor: izrada autora, rezultati modela - rezultati funkcije historijske dekompozicije

Slika 8 ukazuje na relativno umjeren doprinos šoka promjene aktive ESB-a fluktuaciji varijabli. i OBV.

Slika 23 ukazuje na poredak doprinosa po jačini: NEZ, IND, BUR, IZVOZ, KRED 
Sve varijable u snažnom su oporavku od kraja 2012. godine, osim kreditne aktivnosti banaka, koja je u padu tijekom promatranog razdoblja. Model pokazuje odražavanje šoka aktive ESB-a i šoka izvoza na oporavak industrijske proizvodnje i pad nezaposlenosti u drugoj polovici promatranog razdoblja. Na stopu nezaposlenosti najveći utjecaj imao je šok kreditne aktivnosti.

Transmisijski kanali po važnosti: kanal cijena (dionica) imovine, kanal bankovnog kreditiranja, kanal izvoza pa kanal uravnoteženja portfelja.

Na slici 24 vidljiv je trenutačni odziv svih varijabli s vrhom odziva: IND, NEZ, KRED i IZVOZ (u 2. mjesecu) te OBV i BUR (u 3. mjesecu).
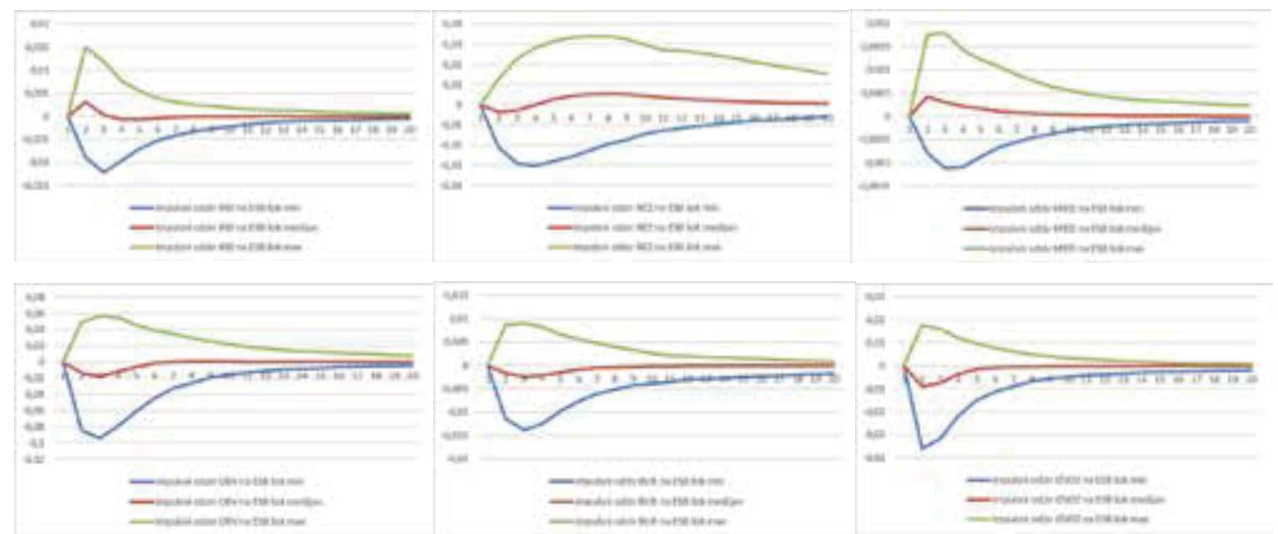

Slika 24. Funkcije impulsnog odziva na šok aktive ESB-a: Irska

Izvor: izrada autora, rezultati modela

\section{9) Italija:}
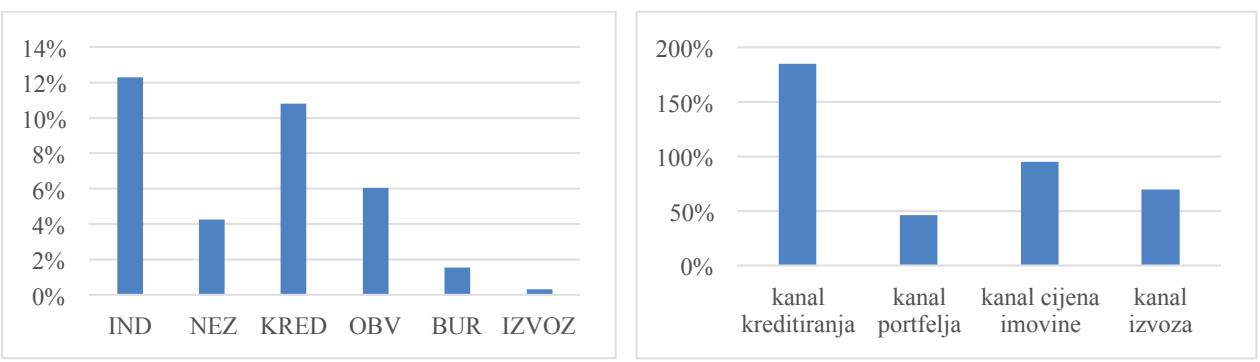

Slika 25. Italija - doprinos šoka aktive ESB-a fluktuaciji varijabli i transmisijski kanali

Izvor: izrada autora, rezultati modela - rezultati funkcije historijske dekompozicije

Slika 8 ukazuje na relativno manji doprinos šoka promjene aktive ESB-a fluktuaciji varijabli.

Slika 25 ukazuje na poredak doprinosa po jačini: IND, KRED, OBV, NEZ, BUR i IZVOZ. 
Italija, koja, osim burzovnog pada, nije jače osjetila udar globalne financijske zaraze 2008. godine, svoju krizu doživljava krajem 2010. godine s popratnim porastom nezaposlenosti i kamata na državne obveznice. Rezultat modela ukazuje na doprinos šoka aktive ESB-a kako na realne, tako i na financijske varijable. Fluktuaciji stope nezaposlenosti doprinijeli su naročito šok kamate na obveznice, ali i šok izvoza, a industrijskoj proizvodnji podjednako svi šokovi.

Transmisijski kanali po važnosti: kanal bankovnog kreditiranja, kanal cijena (dionica) imovine, kanal izvoza pa kanal uravnoteženja portfelja.

Na slici 26 vidljiv je trenutačni odziv svih varijabli s vrhom odziva: NEZ, KRED, OBV i BUR (u 2. mjesecu) te IND i IZVOZ (u 3. mjesecu).
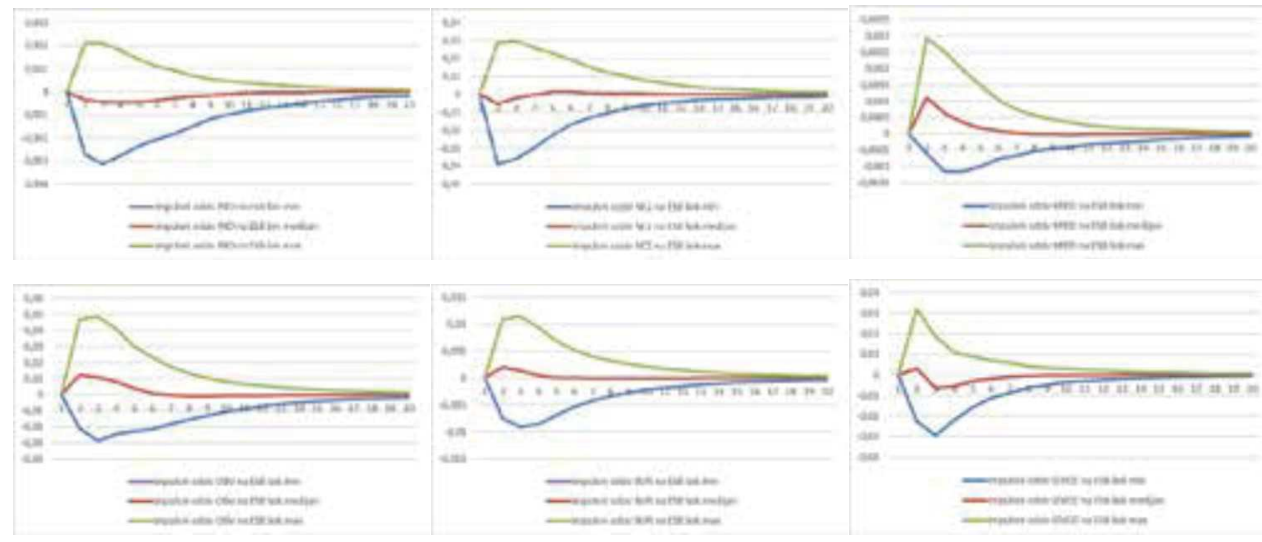

Slika 26. Funkcije impulsnog odziva na šok aktive ESB-a: Italija

Izvor: izrada autora, rezultati modela

\section{0)Letonija:}
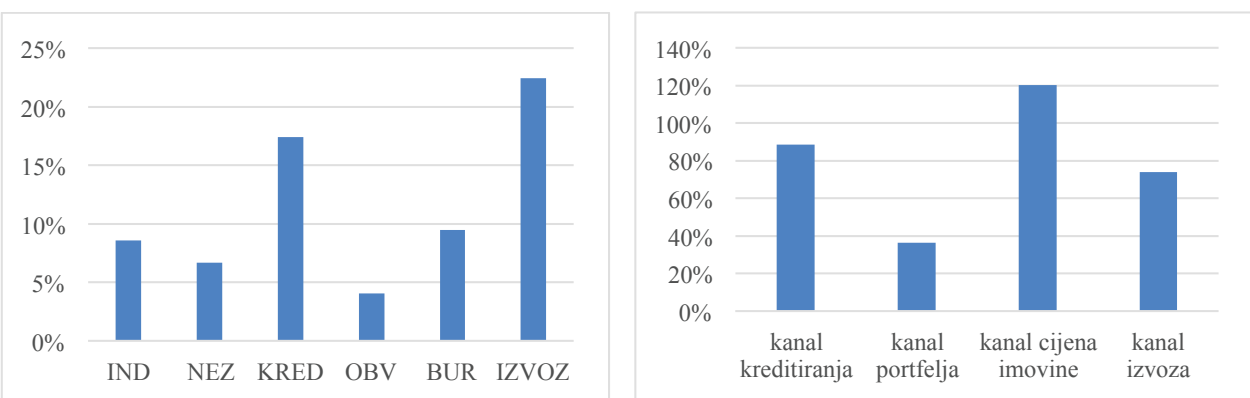

Slika 27. Letonija - doprinos šoka aktive ESB-a fluktuaciji varijabli i transmisijski kanali

Izvor: izrada autora, rezultati modela - rezultati funkcije historijske dekompozicije

Slika 8 ukazuje na relativno veći doprinos šoka promjene aktive ESB-a fluktuaciji varijabli. 
Slika 27 ukazuje na poredak doprinosa po jačini: IZVOZ, KRED, BUR, IND, NEZ i OBV.

Šok aktive ESB-a značajno doprinosi industrijskoj proizvodnji neposredno nakon prvog intenzivnog perioda rasta aktive od kraja 2012. do kraja 2014. godine. Značajan doprinos vidljiv je i kod šoka izvoza. Padu stope nezaposlenosti u periodu 2011. - 2015. godine doprinijeli su šok aktive ESB-a, šok kreditne aktivnosti banaka te šok izvoza. I kod financijskih varijabli primjetan je značajan doprinos šoka aktive ESB-a u periodu od kraja 2012. do kraja 2014. godine.

Transmisijski kanali po važnosti: kanal cijena (dionica) imovine, kanal bankovnog kreditiranja, kanal izvoza pa kanal uravnoteženja portfelja.

Na slici 28 vidljiv je trenutačni odziv svih varijabli s vrhom odziva: IND, KRED i IZVOZ (u 2. mjesecu), OBV (u 3. mjesecu) i BUR (u 4. mjesecu). NEZ reagira tek nakon 2. mjeseca i dostiže vrh u 6 . mjesecu od nastanka šoka.
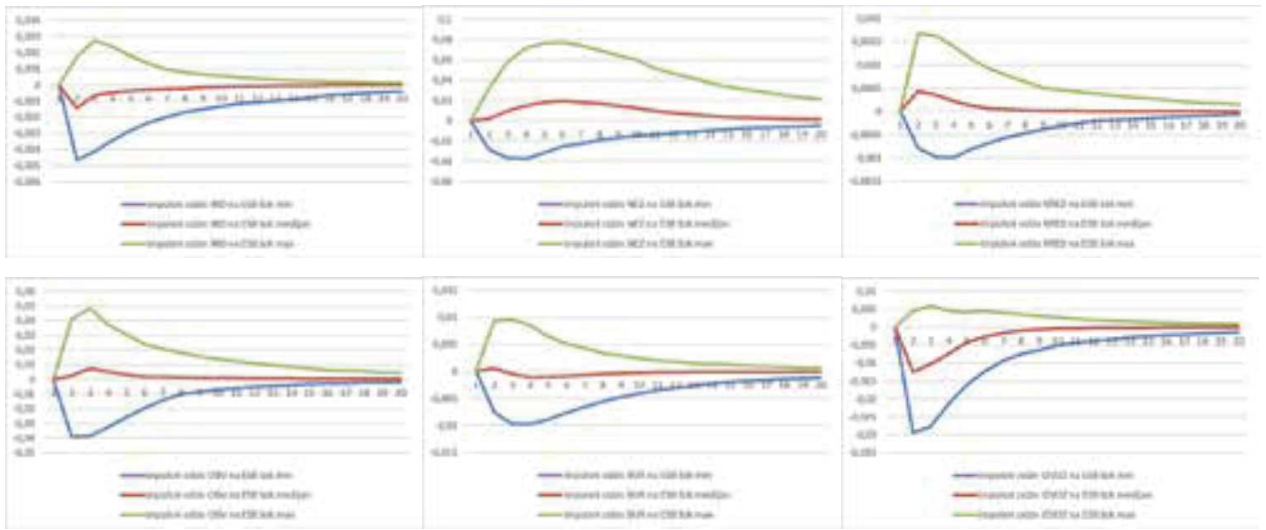

Slika 28. Funkcije impulsnog odziva na šok aktive ESB-a: Letonija

Izvor: izrada autora, rezultati modela

\section{1)Litva:}
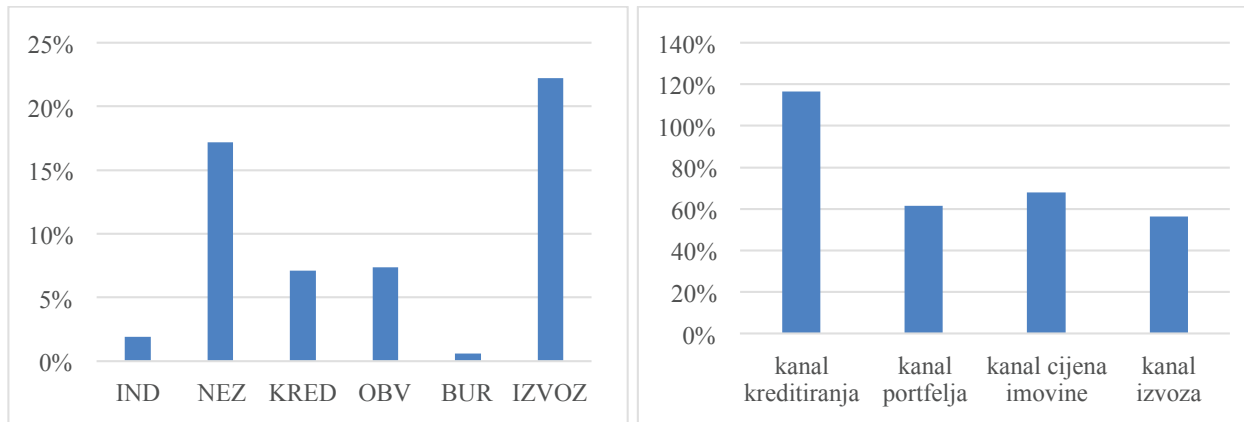

Slika 29. Litva - doprinos šoka aktive ESB-a fluktuaciji varijabli i transmisijski kanali

Izvor: izrada autora, rezultati modela - rezultati funkcije historijske dekompozicije 
Slika 8 ukazuje na relativno umjeren doprinos šoka promjene aktive ESB-a fluktuaciji varijabli.

Slika 29 ukazuje na poredak doprinosa po jačini: IZVOZ, NEZ, OBV, KRED, IND i BUR.

Na stope industrijske proizvodnje i nezaposlenosti dominantno djeluju šok kreditne aktivnosti, šok aktive ESB-a te potom i šok izvoza. Šok aktive ESB-a im doprinosi od sredine 2011. godine pa sve do kraja promatranog razdoblja, no s mnogo jačim doprinosom u periodima povećanja aktive 2011. - 2012. godine i smanjenja 2013. - 2014. godine nego u ostatku promatranog razdoblja. Od ostalih varijabli šok aktive snažnije je utjecao na izvoz, obvezničke prinose i kreditnu aktivnost. Transmisijski kanali po važnosti: kanal bankovnog kreditiranja, kanal cijena (dionica) imovine, kanal uravnoteženja portfelja pa kanal izvoza.

Na slici 30 vidljiv je trenutačni odziv svih varijabli s vrhom odziva: IZVOZ (u 2. mjesecu), IND, KRED, OBV i BUR (u 3. mjesecu) te NEZ (u 7. mjesecu).
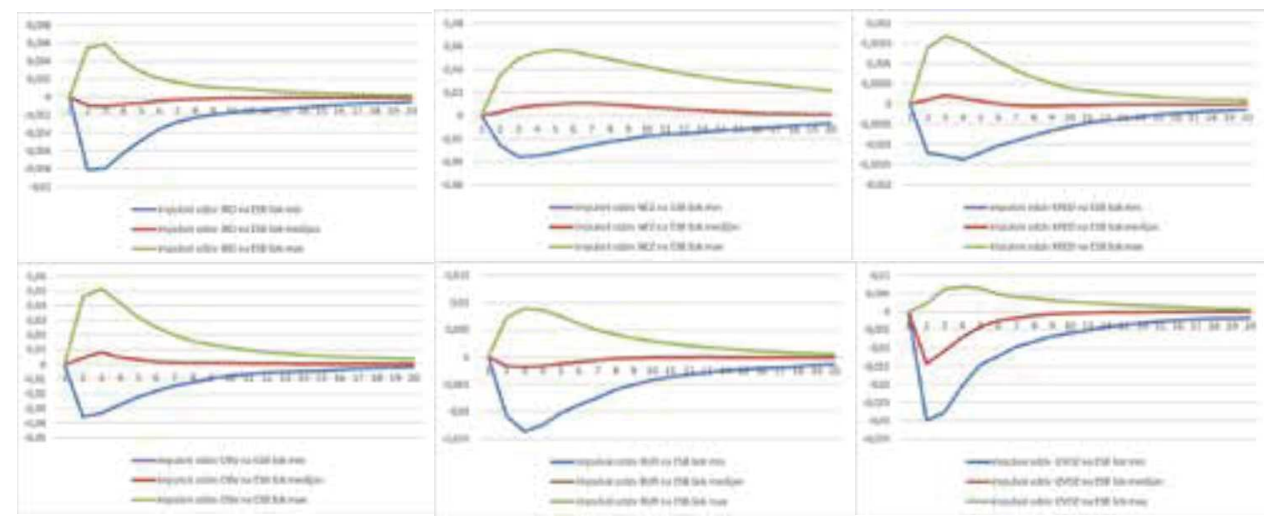

Slika 30. Funkcije impulsnog odziva na šok aktive ESB-a: Litva

Izvor: izrada autora, rezultati modela

\section{2)Luksemburg:}
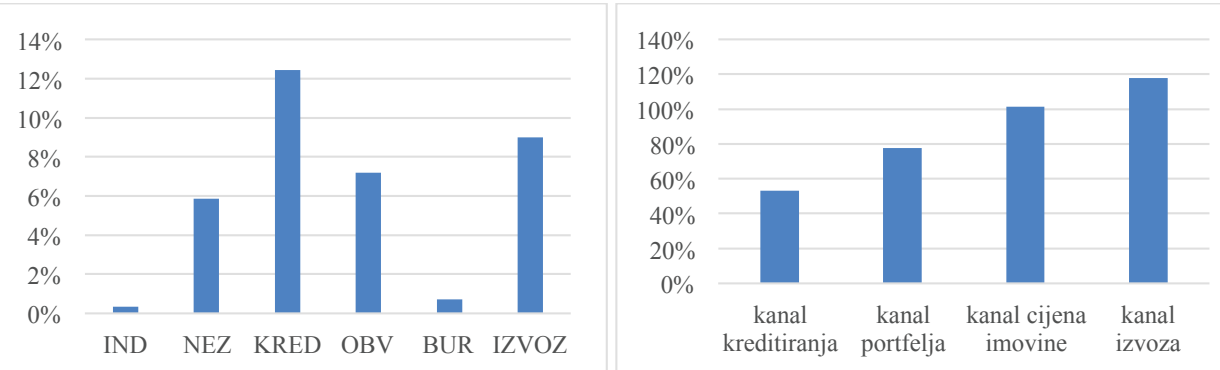

Slika 31. Luksemburg - doprinos šoka aktive ESB-a fluktuaciji varijabli i transmisijski kanali

Izvor: izrada autora, rezultati modela - rezultati funkcije historijske dekompozicije 
Slika 8 ukazuje na relativno manji doprinos šoka promjene aktive ESB-a fluktuaciji varijabli.

Slika 31 upućuje na poredak doprinosa po jačini: KRED, IZVOZ, OBV, NEZ, BUR i IND.

Rezultati modela ukazuju na odraz šoka aktive ESB-a na sve varijable modela, osim na industrijsku proizvodnju i burzovnu aktivnost. Šok aktive ESB-a značajnije utječe kroz prvi period intenzivnog povećanja aktive te kroz period smanjenja aktive do konca 2014. godine u odnosu na period povećanja aktive od 2015. godine do kraja promatranog razdoblja. Na industrijsku proizvodnju najviše djeluje šok izvoza, a na nezaposlenost šok kreditne aktivnosti.

Transmisijski kanali po važnosti: kanal izvoza, kanal cijena imovine, kanal uravnoteženja portfelja pa kanal bankovnog kreditiranja.

Na slici 32 vidljiv je trenutačni odziv svih varijabli s vrhom odziva: KRED (u 2. mjesecu), IND, IZVOZ, OBV, BUR i NEZ (u 3. mjesecu).
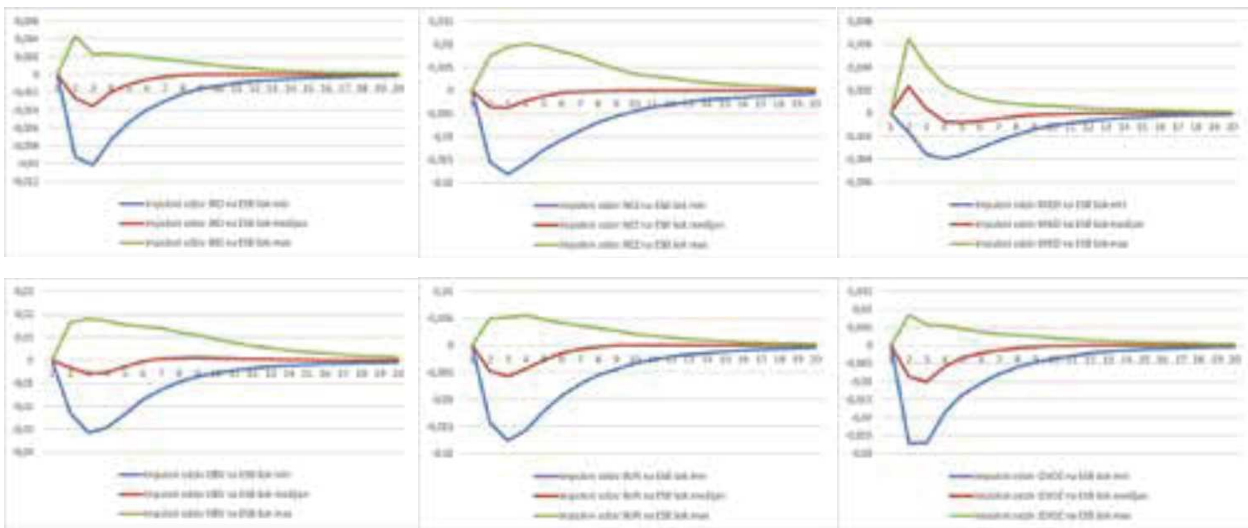

Slika 32. Funkcije impulsnog odziva na šok aktive ESB-a: Luksemburg

Izvor: izrada autora, rezultati modela

\section{3)Malta:}

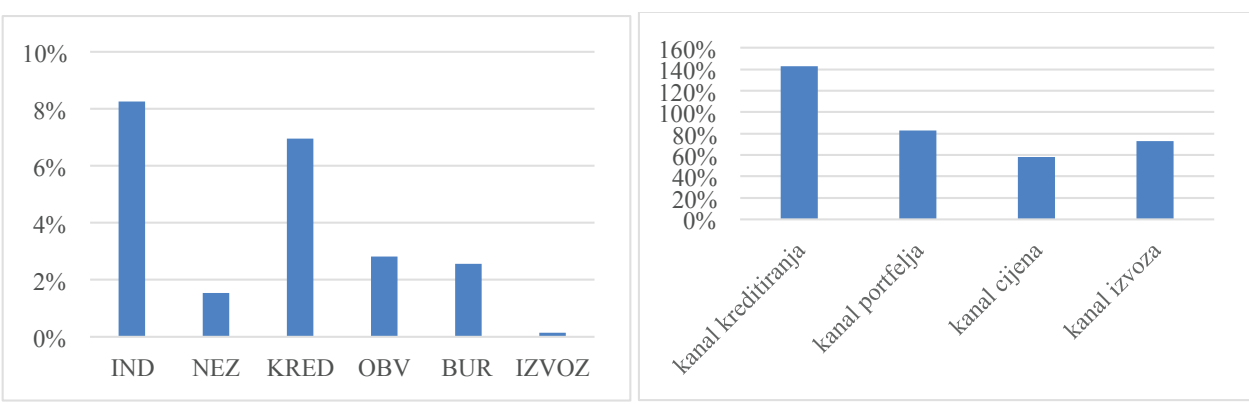

Slika 33. Malta - doprinos šoka aktive ESB-a fluktuaciji varijabli i transmisijski kanali 
Slika 8 ukazuje na relativno manji doprinos šoka promjene aktive ESB-a fluktuaciji varijabli.

Slika 33 upućuje na poredak doprinosa po jačini: IND, KRED, OBV, BUR, NEZ i IZVOZ.

Šok aktive ESB-a više je utjecao na nezaposlenost, industrijsku proizvodnju te posebice na kamatu na obveznice i izvoz tijekom prvog perioda intenzivnije promjene aktive.

Na stopu nezaposlenosti i industrijsku proizvodnju najveći utjecaj imali su šok kreditne aktivnosti (negativno na početku promatranog perioda i pozitivno pred kraj) i šok obvezničkih prinosa s pretežito pozitivnim doprinosom.

Transmisijski kanali po važnosti: kanal bankovnog kreditiranja, kanal uravnoteženja portfelja, kanal izvoza pa kanal cijena (dionica) imovine.

Na slici 34 vidljiv je trenutačni odziv svih varijabli s vrhom odziva: IND, IZVOZ, OBV, BUR i NEZ (u 2. mjesecu) te KRED (u 3. mjesecu).
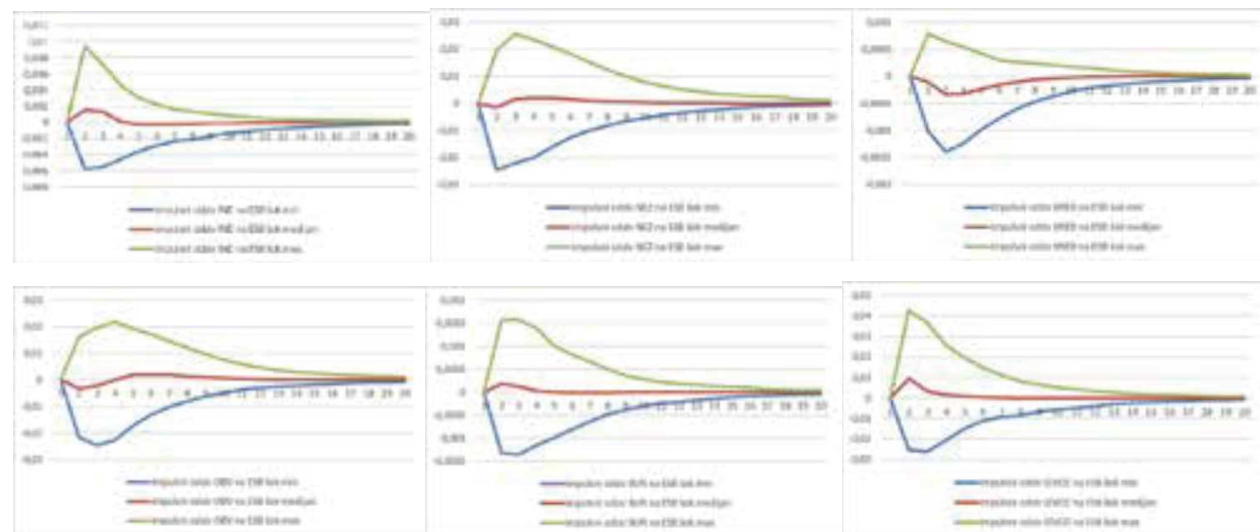

Slika 34. Funkcije impulsnog odziva na šok aktive ESB-a: Malta

Izvor: izrada autora, rezultati modela

\section{4) Nizozemska:}
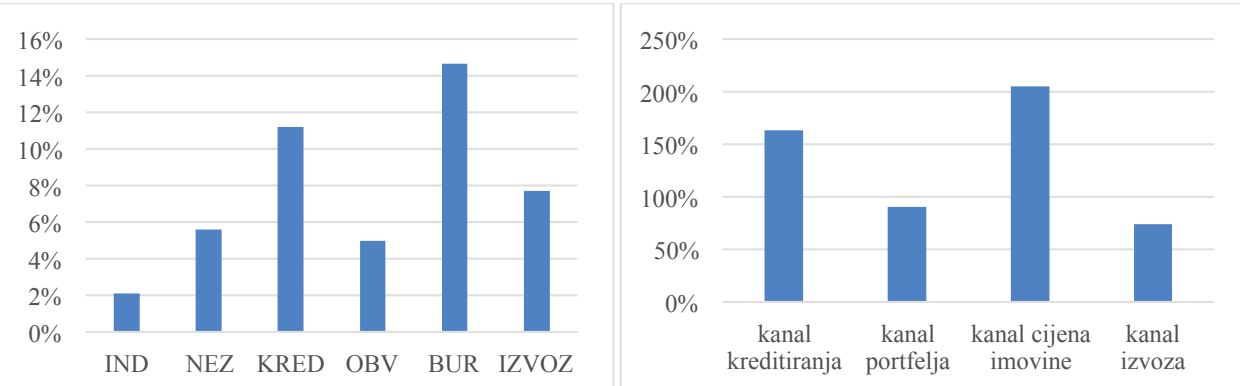

Slika 35. Nizozemska - doprinos šoka aktive ESB-a fluktuaciji varijabli i transmisijski kanali 
Slika 8 ukazuje na relativno umjeren doprinos šoka promjene aktive ESB-a fluktuaciji varijabli.

Slika 35 upućuje na poredak doprinosa po jačini: BUR, KRED, IZVOZ, NEZ, OBV i IND.

Utjecaj šoka aktive intenzivniji je od 2011. do 2015. godine nego u ostatku promatranog razdoblja. U modelu je dominantan šok burzovne aktivnosti. Od ostalih, na nezaposlenost je najviše utjecao šok obvezničkih prinosa i šok kreditne aktivnosti. Na industrijsku proizvodnju izrazito je utjecao šok kreditne aktivnosti.

Transmisijski kanali po važnosti: kanal cijena (dionica) imovine, kanal bankovnog kreditiranja, kanal uravnoteženja portfelja pa kanal izvoza.

Na slici 36 vidljiv je trenutačni odziv svih varijabli s vrhom odziva: BUR, KRED i NEZ (u 2. mjesecu), IZVOZ i IND (u 3. mjesecu) te OBV (u 4. mjesecu).
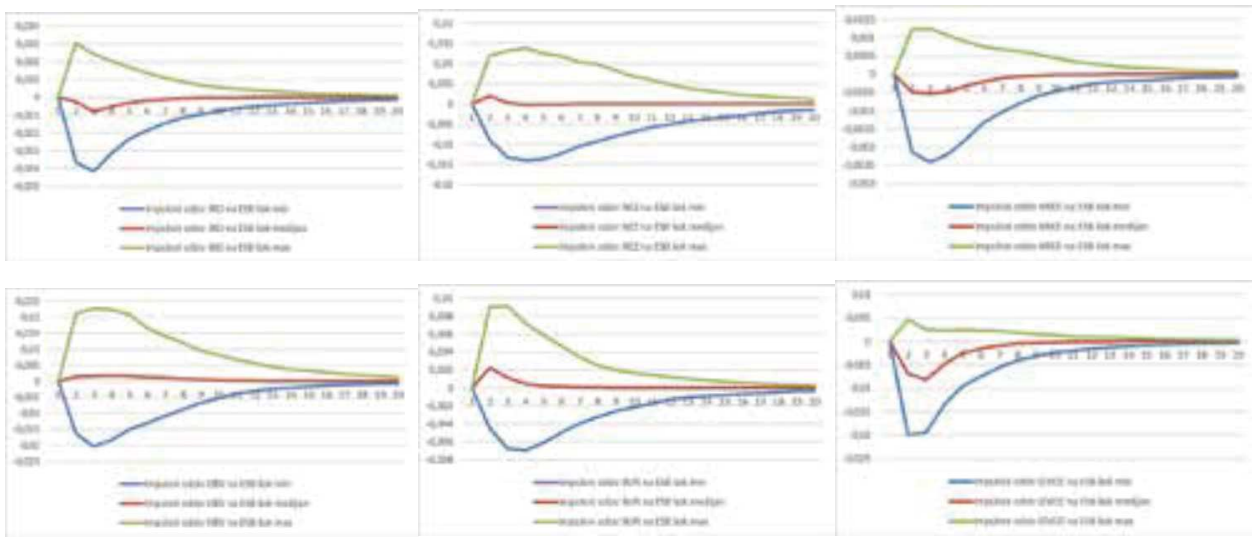

Slika 36. Funkcije impulsnog odziva na šok aktive ESB-a: Nizozemska

Izvor: izrada autora, rezultati modela

\section{5) Njemačka:}
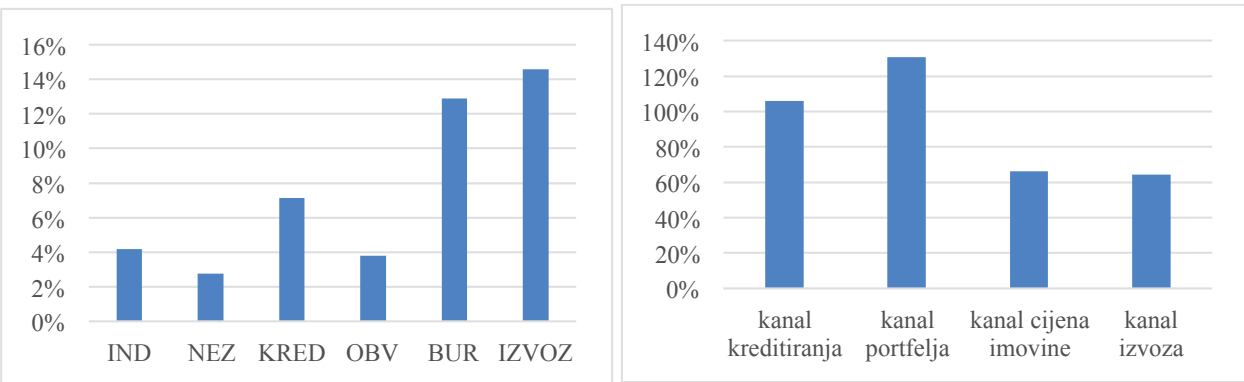

Slika 37. Njemačka - doprinos šoka aktive ESB-a fluktuaciji varijabli i transmisijski kanali

Izvor: izrada autora, rezultati modela - rezultati funkcije historijske dekompozicije 
Slika 8 ukazuje na relativno umjeren doprinos šoka promjene aktive ESB-a fluktuaciji varijabli.

Slika 37 upućuje na poredak doprinosa po jačini: IZVOZ, BUR, KRED, IND, OBV i NEZ.

Trajniji pozitivan doprinos šoka aktive ESB-a vidljiv je na nezaposlenosti, obvezničkim prinosima, izvozu i industrijskoj proizvodnji. Na varijablu nezaposlenosti snažno djeluje i šok obvezničkih prinosa. Porastu nezaposlenosti tijekom 2009. godine snažno je doprinio šok smanjenja kreditne aktivnosti banaka. Obrnuta situacija je od 2012. do 2014. godine, kada je šok kreditiranja banaka snažno utjecao na smanjenje nezaposlenosti. Industrijskoj proizvodnji, koja, osim koncem 2008. godine, pokazuje stabilnost, snažno pozitivno doprinose šok kreditne aktivnosti i izvoza. Transmisijski kanali po važnosti: kanal uravnoteženja portfelja, kanal bankovnog kreditiranja, kanal cijena (dionica) imovine pa kanal izvoza.

Na slici 38 vidljiv je trenutačni odziv varijabli s vrhom odziva: IND, BUR i KRED (u 2. mjesecu), IZVOZ (u 3. mjesecu) i NEZ (u 5. mjesecu). OBV kasni dva mjeseca (vrh u 4. mjesecu).
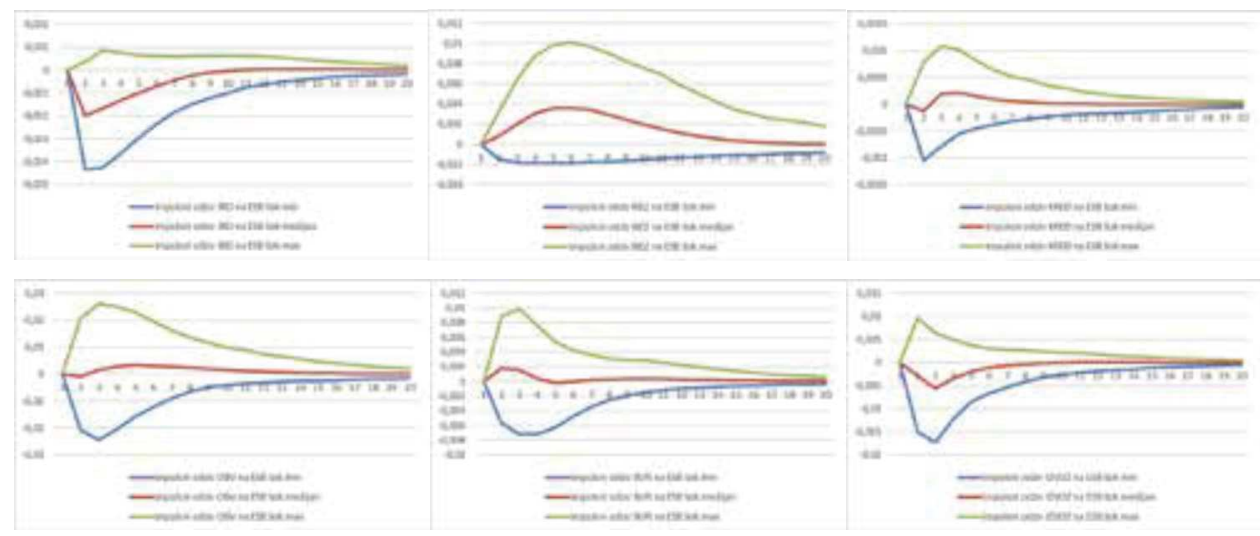

Slika 38. Funkcije impulsnog odziva na šok aktive ESB-a: Njemačka

Izvor: izrada autora, rezultati modela

\section{6) Portugal:}
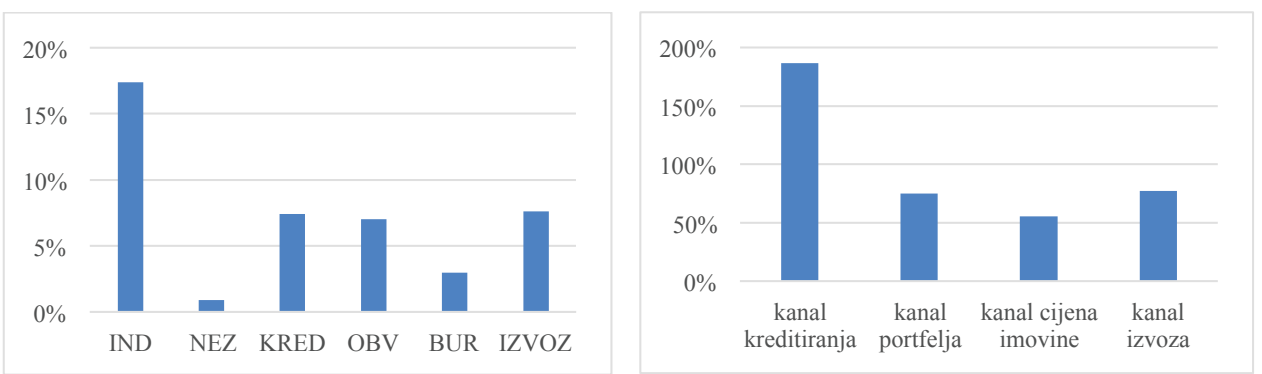

Slika 39. Portugal - doprinos šoka aktive ESB-a fluktuaciji varijabli i transmisijski kanali 
Slika 8 ukazuje na relativno umjeren doprinos šoka promjene aktive ESB-a fluktuaciji varijabli.

Slika 39 upućuje na poredak doprinosa po jačini: IND, IZVOZ, KRED, OBV, BUR i NEZ.

Rezultati modela pokazuju jaki učinak šoka aktive ESB-a na sve varijable, a ponajviše na nezaposlenost, industrijsku proizvodnju i obvezničke prinose. Šok aktive ESB-a djelovao je jače u periodima promjene aktive 2011. - 2014. godine u odnosu na 2015. - 2017. godine. Šok kreditne aktivnosti doprinosio je snažno negativno od 2008. do kraja 2011. godine, dok je u ostatku promatranog razdoblja taj doprinos bio snažno pozitivan. Model također bilježi jaki utjecaj obvezničkog šoka na varijablu nezaposlenosti.

Transmisijski kanali po važnosti: kanal bankovnog kreditiranja, kanal izvoza, kanal uravnoteženja portfelja pa kanal cijena (dionica) imovine.

Na slici 40 vidljiv je trenutačni odziv varijabli s vrhom odziva: OBV, BUR i IZVOZ (u 2. mjesecu), IND i KRED (u 3. mjesecu), NEZ (u 4. mjesecu).
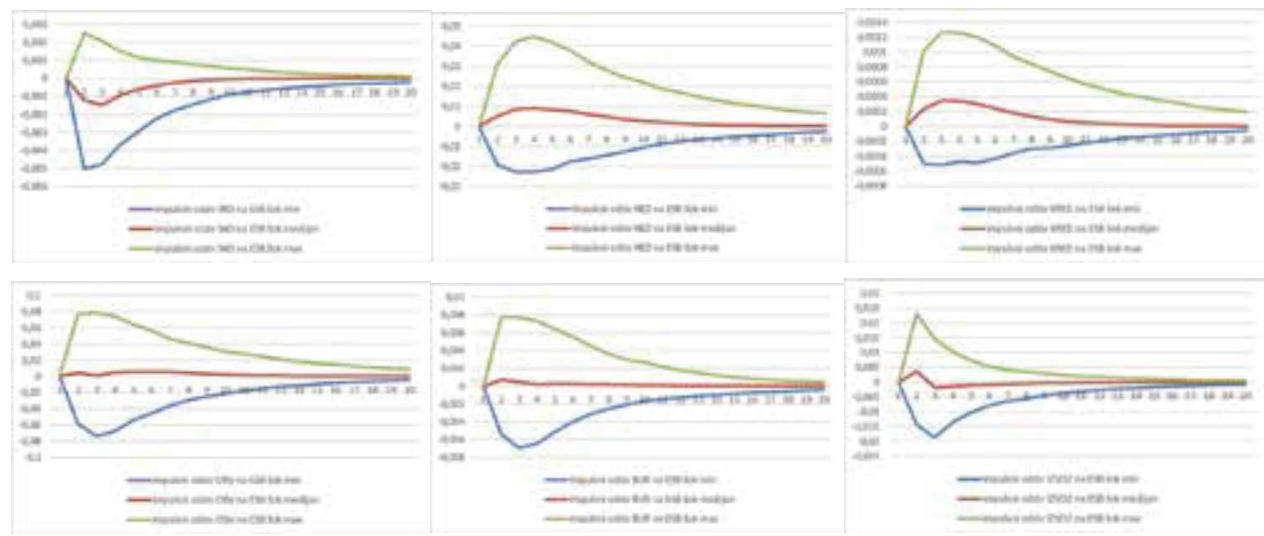

Slika 40. Funkcije impulsnog odziva na šok aktive ESB-a: Portugal

Izvor: izrada autora, rezultati modela

\section{7) Slovenija:}
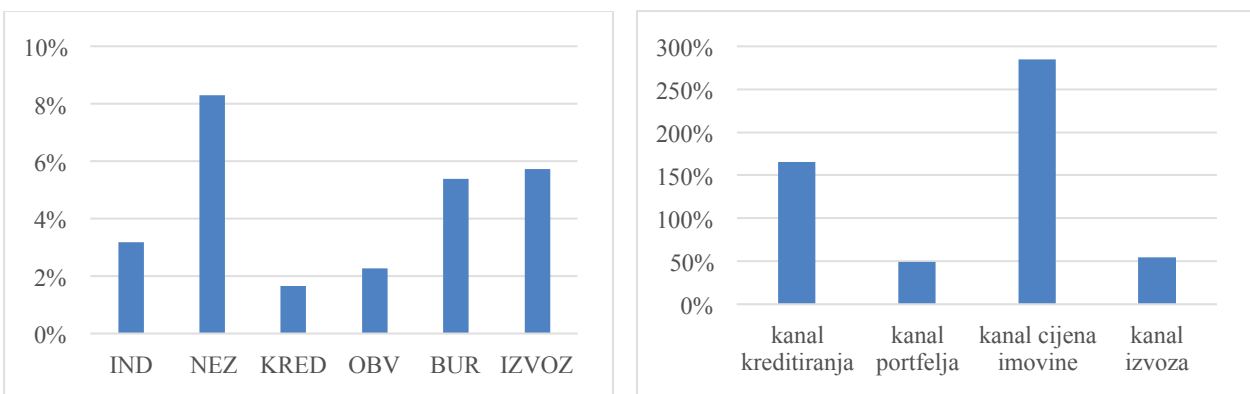

Slika 41. Slovenija - doprinos šoka aktive ESB-a fluktuaciji varijabli i transmisijski kanali

Izvor: izrada autora, rezultati modela - rezultati funkcije historijske dekompozicije 
Slika 8 ukazuje na relativno manji doprinos šoka promjene aktive ESB-a fluktuaciji varijabli.

Slika 41 upućuje na poredak doprinosa po jačini: NEZ, IZVOZ, BUR, IND, OBV i KRED.

Doprinos šoka aktive ESB-a najintenzivniji je od 2011. - 2015. godine. Do sredine 2011. godine kreditni šok pozitivno doprinosi kretanju nezaposlenosti, dok je u ostatku promatranog razdoblja obrnutog, negativnog doprinosa. Obveznički šok još snažnije doprinosi nezaposlenosti, ali sa češćim izmjenama iz pozitivnog u negativni doprinos i obrnuto.

Transmisijski kanali po važnosti: kanal cijena (dionica) imovine, kanal bankovnog kreditiranja, kanal izvoza pa kanal uravnoteženja portfelja.

Na slici 42 vidljiv je trenutačni odziv varijabli s vrhom odziva: KRED (u 2. mjesecu), IND, IZVOZ (u 3. mjesecu) i NEZ (u 5. mjesecu). OBV i BUR kasne dva mjeseca i vrh imaju u 4. (OBV) i 3. (BUR) mjesecu.
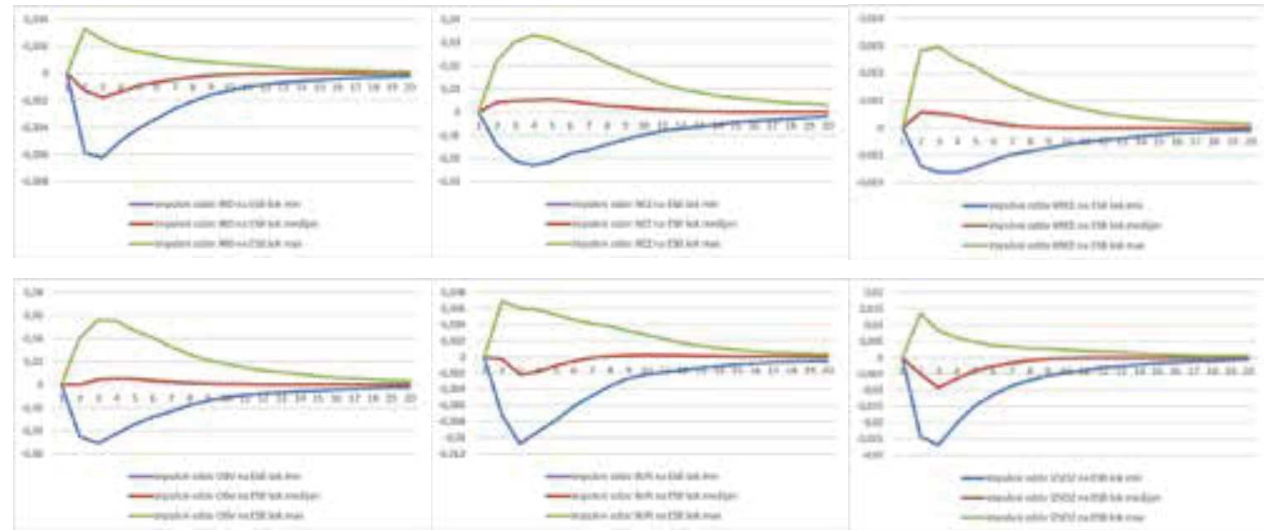

Slika 42. Funkcije impulsnog odziva na šok aktive ESB-a: Slovenija

Izvor: izrada autora, rezultati modela

\section{8) Slovačka:}
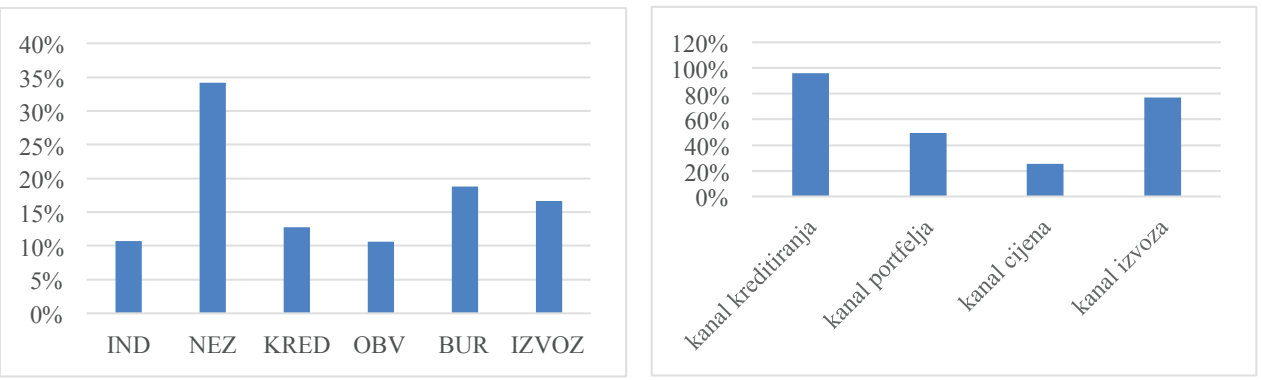

Slika 43. Slovačka - doprinos šoka aktive ESB-a fluktuaciji varijabli i transmisijski kanali

Izvor: izrada autora, rezultati modela - rezultati funkcije historijske dekompozicije 
Slika 8 ukazuje na relativno veći doprinos šoka promjene aktive ESB-a fluktuaciji varijabli.

Slika 43 upućuje na poredak doprinosa po jačini: NEZ, BUR, IZVOZ, KRED, IND i OBV.

Šok aktive ESB-a snažno utječe na izvoz, nezaposlenost i snižavanje kamata na obveznice tijekom perioda 2011. - 2014. godine. U usporedbi s ostalim šokovima, šok aktive snažnije doprinosi nezaposlenosti i industrijskoj proizvodnji. Kreditni šok uglavnom negativno doprinosi stopi nezaposlenosti od 2009. do 2014. godine, kada taj doprinos prelazi u pozitivni.

Transmisijski kanali po važnosti: kanal bankovnog kreditiranja, kanal izvoza, kanal uravnoteženja portfelja pa kanal cijena (dionica) imovine.

Na slici 44 vidljiv je trenutačni odziv varijabli s vrhom odziva: IND, KRED i BUR (u 2. mjesecu), OBV i IZVOZ (u 3. mjesecu) te NEZ (u 4. mjesecu).
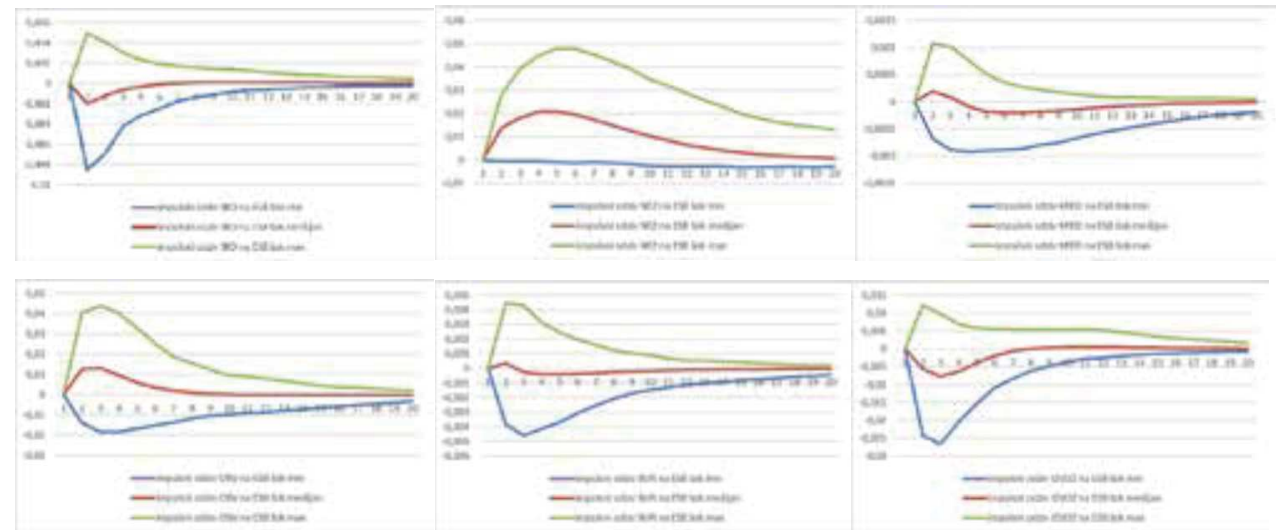

Slika 44. Funkcije impulsnog odziva na šok aktive ESB-a: Slovačka

Izvor: izrada autora, rezultati modela

\section{9) Španjolska:}
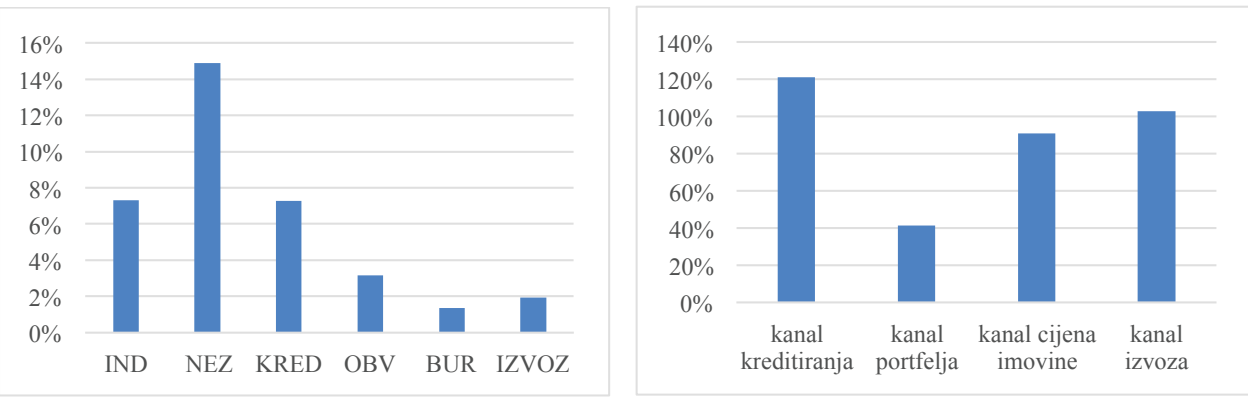

Slika 45. Španjolska - doprinos šoka aktive ESB-a fluktuaciji varijabli i transmisijski kanali

Izvor: izrada autora, rezultati modela - rezultati funkcije historijske dekompozicije 
Slika 8 ukazuje na relativno manji doprinos šoka promjene aktive ESB-a fluktuaciji varijabli.

Slika 45 upućuje na poredak doprinosa po jačini: NEZ, IND, KRED, OBV, IZVOZ i BUR.

Kreditni šok snažno negativno doprinosi varijablama industrijske proizvodnje i nezaposlenosti do kraja 2011. godine, a od tada uglavnom pozitivno. Kod obvezničkog šoka to je obrnut slučaj u istim periodima vremena.

Transmisijski kanali po važnosti: kanal bankovnog kreditiranja, kanal izvoza, kanal cijena (dionica) imovine pa kanal uravnoteženja portfelja.

Na slici 46 vidljiv je trenutačni odziv varijabli s vrhom odziva: KRED (u 2. mjesecu), IND, NEZ, OBV i IZVOZ (u 3. mjesecu), BUR ima zanemarivo malu reakciju na šok aktive.
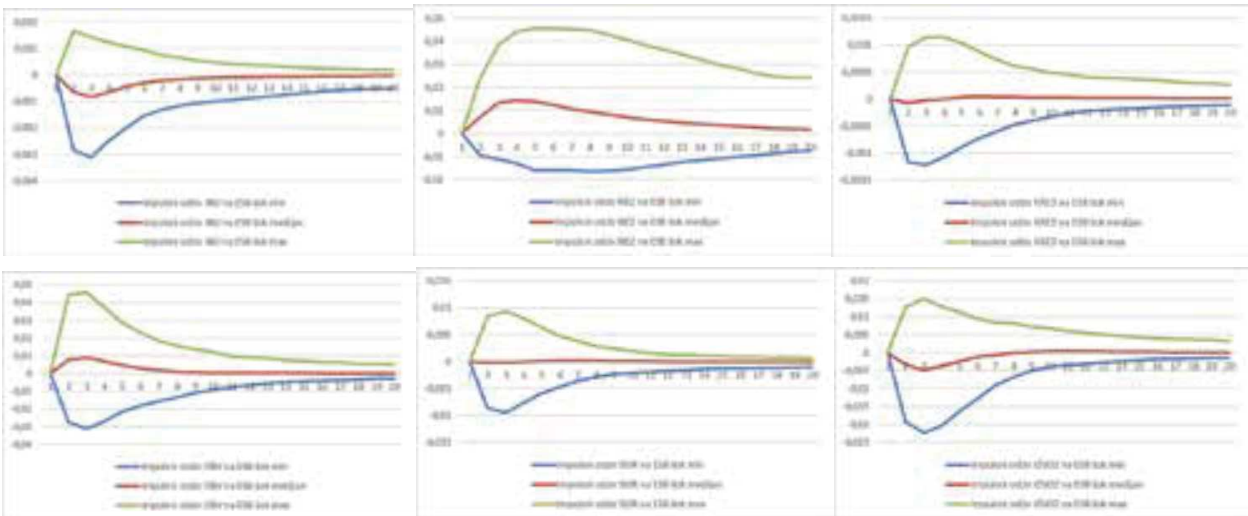

Slika 46. Funkcije impulsnog odziva na šok aktive ESB-a: Španjolska

Izvor: izrada autora, rezultati modela

Zamjenom varijable ukupne aktive ESB-a sa 7.1. stavkom aktive „Vrijednosni papiri držani za potrebe monetarne politike“ dobiju se rezultati prikazani na slikama 47 i 48 na osnovi kojih se može zaključiti da su dobiveni rezultati u skladu s osnovnim modelom.
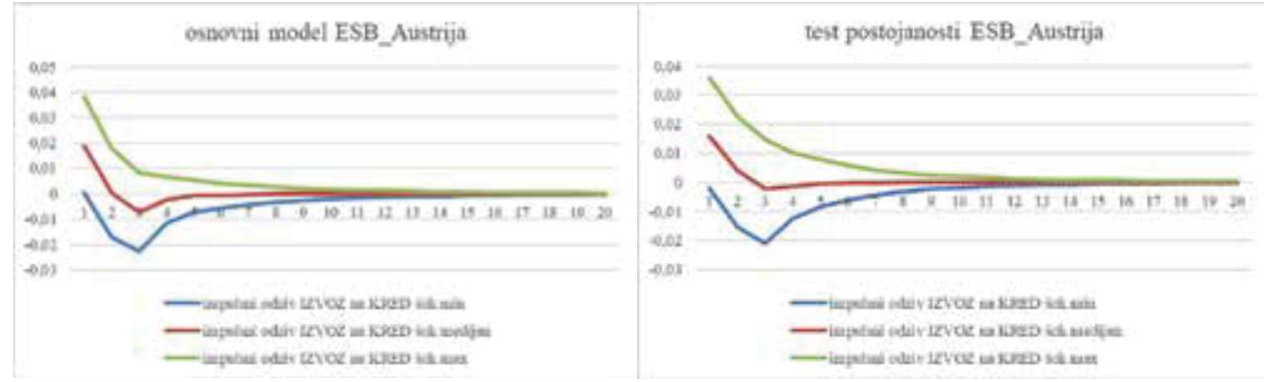

Slika 47. Test postojanosti: funkcija impulsnog odziva IZVOZ-a na šok KRED-a: Austrija

Izvor: izrada autora, rezultati modela 


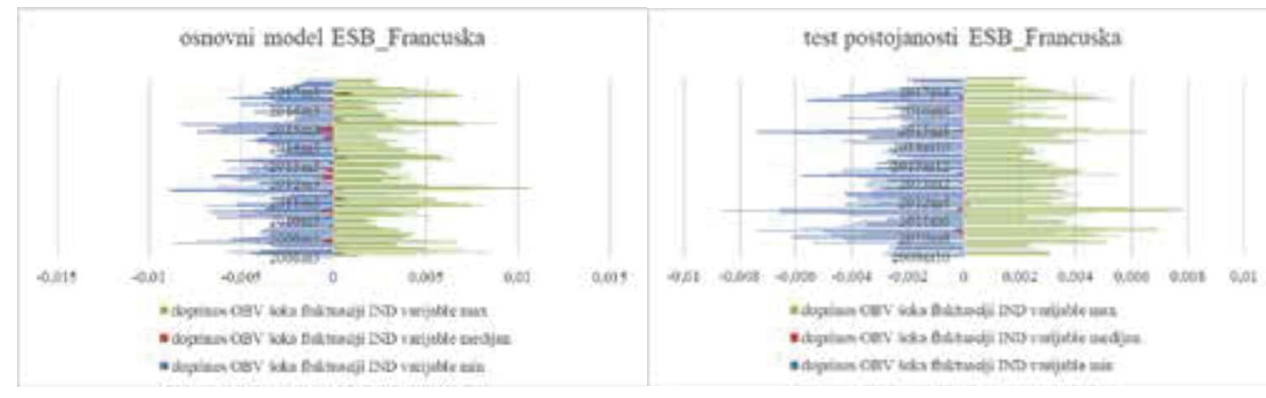

Slika 48. Test postojanosti: funkcija historijske dekompozicije doprinosa šoka OBV-a fluktuaciji IND-a: Francuska

Izvor: izrada autora, rezultati modela

\section{ZAKLJUČAK}

Sinteza rezultata provedenog istraživanja upućuje na nekoliko indikativnih zaključaka. Prvo, nekonvencionalne mjere monetarne politike ESB-a imale su, statistički gledano, relativno značajan doprinos fluktuaciji varijabli provedenih 19 (modela) zemalja europodručja. Drugo, promatrajući europodručje u cjelini, relativno manji doprinos šoka promjene aktive ESB-a bilježi se kod fluktuacije financijskih varijabli - obvezničkih prinosa i burzovne aktivnosti u odnosu na realne varijable modela - izvoz, industrijska proizvodnja i nezaposlenost. Takav zaključak odudara od zapažanja relevantnih istraživanja obuhvaćenih popisom literature koja uglavnom ističu jači doprinos obvezničkim prinosima i burzovnoj aktivnosti. Iako je, promatrajući europodručje u cjelini, glavnina transmisije prošla putem financijskih kanala (kanala kreditiranja banaka i kanala cijena (dionica) imovine), u konačnici je snažniji doprinos provedenih paketa kupnji imovine pružen realnim varijablama modela. Snažniji doprinos kretanju obvezničkih prinosa i burzovne aktivnosti vidljiv je kod zemalja koje imaju visoko razvijen financijski sustav (Nizozemska, Njemačka, Austrija, Luksemburg, Finska, ali i Estonija), što upućuje na potvrdu zaključaka dosadašnjih istraživanja da se nekonvencionalne mjere jače odražavaju kroz razvijeniji financijski sustav. Relativno snažniji doprinos šoka aktive ESB-a vidljiv je kod kreditne aktivnosti banaka, koja je po ukupnom doprinosu odmah iza varijable izvoza. Na kreditnu aktivnost banaka šok aktive ESB-a djelovao je relativno snažno u modelima Belgije, Finske, Grčke, Letonije, Nizozemske i Njemačke.

Prepoznaju se dva intenzivna perioda povećanja aktive ESB-a: (1) sredina 2011. sredina 2012., kada se postigao udruženi učinak Programa tržišta vrijednosnih papira (SMP), Programa kupnje pokrivenih obveznica (CBPP), Programa kupnje pokrivenih obveznica 2 (CBPP2) te redovitih tromjesečnih i šestomjesečnih operacija dugoročnog refinanciranja (LTROs), te (2) od kraja 2014. pa nadalje, kada je ESB proveo Programe kupnje imovine (APP) uz nastavak faze reinvestiranja dospjelih glavnica sve do 2018. godine. Na financijske varijable snažnije je djelovao šok aktive ESB-a tijekom prvog perioda povećanja aktive kod većine zemalja. Treće, na realne varijable modela učinci su pretežno pozitivni i donekle snažniji u odnosu na rezultate većine relevantnih istraživanja obuhvaćenih po- 
pisom literature. Šok aktive ESB-a snažnije je izražen na realnim varijablama u odnosu na financijske kod zemalja koje su imale krizu javnog duga - Cipar, Irska, Grčka, Italija, Portugal, ali i Slovačka, Finska i Francuska. Kod tih zemalja nekonvencionalne mjere ESB-a imale su kroz bilancu relativno snažan utjecaj na industrijsku proizvodnju. Periodi intenzivne promjene aktive ESB-a kod se većine zemalja uzorka poklapaju s pozitivnom tendencijom promjene industrijske proizvodnje, dok se period smanjenja aktive vremenski podudara s negativnom tendencijom promjene stope industrijske proizvodnje. Šok aktive ESB-a na nezaposlenost je djelovao relativno snažno u modelima Finske, Francuske, Irske, Litve i Slovačke. U dva perioda intenzivnog rasta aktive ESB-a uglavnom je došlo do snižavanja stope nezaposlenosti, dok je u periodu smanjenja aktive stopa nezaposlenosti ili usporila pad ili se povećala kod većine promatranih zemalja. Šok aktive izraženije je doprinosio fluktuaciji izvoza kod Austrije, Belgije, Finske, Grčke, Letonije, Litve i Njemačke. Četvrto, za cjelokupno europodručje, kroz promatrani period, najveći utjecaj imao je kanal bankovnog kreditiranja, koji odmah potom po važnosti slijedi kanal cijena (dionica) imovine. Treći po važnosti je kanal izvoza te na kraju kanal uravnoteženja portfelja. Kanal bankovnog kreditiranja dominira kod Cipra, Finske, Italije, Litve, Malte, Portugala, Slovačke i Španjolske. Kanal cijena (dionica) imovine pretežit je kod Austrije, Belgije, Estonije, Grčke, Irske, Letonije, Nizozemske i Slovenije. Kanal izvoza dominira kod Francuske i Luksemburga, a kanal uravnoteženja portfelja kod Njemačke.

Ukupno uzevši, provedene nekonvencionalne mjere ostvarile su makroekonomski utjecaj, pokrenule oporavak realnih i financijskih varijabli. Najsnažniji odraz vidljiv je na izvozu, slijedi utjecaj na kreditnu aktivnost, potom nezaposlenost, industrijsku proizvodnju, obvezničke prinose te najslabiji na burzovnu aktivnost. Ipak, imajući u vidu da je ESB čak triput povećao svoju aktivu, stječe se dojam kako te mjere i nisu bile previše učinkovite s obzirom na njihovu veličinu i intenzitet, jer je većina zemalja u promatranom desetljeću „tek“ ostvarila povrat na pretkrizne razine ekonomskog privređivanja. No, s druge strane, opravdano se zapitati koliko bi Velika recesija držala monetarnu uniju u negativnoj ekonomskoj perspektivi i bi li unija politički opstala da nije bilo tako obilnih i intenzivnih monetarnih mjera.

Iako opsežno, ovo istraživanje obuhvatilo je samo dio varijabli koje čine makroekonomsku stvarnost pa dobivene rezultate treba držati relativnim i čitati ih zajedno s rezultatima dosad provedenih istraživanja na ovu temu. Kao ograničenje stoji i činjenica da je umjesto BDP-a u istraživanju korištena industrijska proizvodnja, čime su izostala mjerenja na sferi usluga. Dobivene rezultate potrebno je tumačiti uzimajući u obzir i rezultate istraživanja učinaka prelijevanja nekonvencionalnih mjera monetarne politike FED-a s obzirom na to da su zemlje uzorka u vremenu promatranja pod utjecajem i tih vanjskih šokova. Važno je temeljito istraživati i čimbenike koji utječu na odražavanje mjera ne bi li se iz svega toga dobile snažnije indicije o brzini odražavanja ovih mjera i potencijalnome vremenskom kašnjenju njihovih učinaka na gospodarstvo. To su svakako preporuke za buduća istraživanja na ovu temu.

\section{LITERATURA}

1. Arias, J.E., Rubio-Ramirez J.F., Waggoner D.F. (2014) Inference based on SVAR identified with sign and zero restrictions: Theory and applications. Working paper, Federal Reserve Bank of Atlanta, No. 2014-1. 
2. Arias, J.E., Rubio-Ramirez J.F., Waggoner D.F. (2018) Inference based on structural vector autoregressions identified with sign and zero restrictions: Theory and applications. Econometrica, Vol. 86, No. 2, March 2018, str. 685-720.

3. Bank for International Settlements (BIS Statistics) database [online]. Dostupno na https://www.bis.org/statistics/cbpol.htm?m=6\%7C382\%7C679 [03. veljače 2020.].

4. Baumeister, C., Benati, L. (2010). Unconventional monetary policy and the great recession - Estimating the impact of a compression in the yield spread at the zero lower bound, ECB Working Paper, br. 1258, European Central Bank (ECB), Frankfurt a. M.

5. Bhattarai, S., Eggertsson, G. B., Gafarov, B. (2015). Time consistency and the duration of government debt: A signalling theory of quantitative easing (br. w21336). National Bureau of Economic Research.

6. Bodenstein, M., Erceg, C.J., Guerrieri, L. (2017). The effects of foreign shocks when interest rates are at zero. Canadian Journal of Economics/Revue canadienne d'économique 50.3, str. 660-684.

7. Bridges, J., Thomas, R. (2012). The impact of QE on the UK economy-some supportive monetarist arithmetic. Working paper br. 442, Bank of England.

8. Casiraghi, M., Gaiotti, E., Rodano, M. L., Secchi, A. (2013). The impact of unconventional monetary policy on the Italian economy during the sovereign debt crisis. Bank of Italy Occasional Paper, (203).

9. Chen, H., Cúrdia, V., Ferrero, A. (2011). The macroeconomic effects of large-scale asset purchase programs, Staff Report, br. 527, Federal Reserve Bank of New York, New York, NY

10. Christensen, J. H., Rudebusch, G. D. (2012). The response of interest rates to US and UK quantitative easing. The Economic Journal, 122 (564), str. 385-414.

11. Chung, H., Laforte, J. P., Reifschneider, D., Williams, J. C. (2012). Have we underestimated the likelihood and severity of zero lower bound events? Journal of Money, Credit and Banking, 44, 47-82.

12. Churm, R., Joyce, M., Kapetanios, G., Theodoridis, K. (2018). Unconventional monetary policies and the macroeconomy: The impact of the UK's QE2 and funding for lending scheme. The Quarterly Review of Economics and Finance.

13. D’Amico, S., English, W., López-Salido, D., Nelson, E. (2012). The Federal Reserve's large-scale asset purchase programmes: rationale and effects. The Economic Journal, 122 (564), F415-F446.

14. Darracq-Paries, M., De Santis, R. A. (2015). A non-standard monetary policy shock: The ECB's 3-year LTROs and the shift in credit supply. Journal of International Money and Finance, 54, str. 1-34.

15. Dieppe, A., Legrand, R., van Roye, B. (2016). The BEAR toolbox. ECB Working Paper 1934, European Central Bank.

16. Eser, F., Schwaab, B. (2016). Evaluating the impact of unconventional monetary policy measures: Empirical evidence from the ECB's Securities Markets Programme. Journal of Financial Economics, 119 (1), str. 147-167.

17. European Central Bank, Monetary policy [online]. Dostupno na: https://www.ecb.europa.eu/mopo/implement/omt/html/index.en.html [23. veljače 2020.] . 
18. European Central Bank Statistical Data Warehouse (SDW) database [online]. Dostupno na https://sdw.ecb.europa.eu [3. veljače 2020.].

19. European Central Bank BEAR Toolbox [online]. Dostupno na https://www.ecb.europa.eu/pub/research/working-papers/html/bear-toolbox.en.html [30. prosinca 2018.].

20. Fratzscher, M., Duca, M. L., Straub, R. (2016). ECB unconventional monetary policy: Market impact and international spillovers. IMF Economic Review, 64 (1), str. 36-74.

21. Gagnon, J. E. (2016). Quantitative easing: An underappreciated success. PIIE Policy Brief, 16.

22. Gagnon, J. E., Bayoumi, T., Londono, J. M., Saborowski, C., Sapriza, H. (2017). Direct and Spillover Effects of Unconventional Monetary and Exchange Rate Policies. Open Economies Review, 28(2), str. 191-232 .

23. Gambacorta, L., Hofmann, B., Peersman, G. (2014). The effectiveness of unconventional monetary policy at the zero lower bound: A cross-country analysis. Journal of Money, Credit and Banking, 46 (4), str. 615-642.

24. Hausken K., Ncube M. (2013). Transmission Channels for QE and Effects on Interest Rates. Quantitative Easing and Its Impact in the US, Japan, the UK and Europe. SpringerBriefs in Economics. Springer, New York, NY.

25. International Monetary Fund (IMF DATA) database [online]. Dostupno na https:// data.imf.org [3. veljače 2020.].

26. Kordić, G. (2018) Use of (hard and soft) pegged exchange rate regimes on the path to european integrations in terms of crisis. Zbornik Radova/Journal of Economy and Business, 2018 (Special Issue), str. 250-266.

27. Lovrinović, I., Ivanov, M. (2009). Monetarna politika. Zagreb: RRIF plus.

28. Meinusch, A., Tillmann, P. (2014). The macroeconomic impact of unconventional monetary policy shocks. MAGKS Joint Discussion Paper Series in Economics, No. 26-2014, Philipps-University Marburg, Faculty of Business Administration and Economics, Marburg.

29. Michaelis, H., Watzka, S. (2017). Are there differences in the effectiveness of quantitative easing at the zero-lower-bound in Japan over time? Journal of International Money and Finance, 70, str. 204-233.

30. Organisation for Economic Co-operation and Development (OECD DATA) database [online]. Dostupno na https://data.oecd.org [3. veljače 2020.].

31. Papadamou, S., Kyriazis, N.A., Tzeremes, P. G. (2019). Unconventional monetary policy effects on output and inflation: A meta-analysis. International Review of Financial Analysis, br. 61, siječanj 2019., str. 295-305.

32. Rogers, J. H., Scotti, C., Wright, J. H. (2014). Evaluating asset-market effects of unconventional monetary policy: a multi-country review. Economic Policy, 29 (80), str. 749-799.

33. World Bank World Development Indicators (WDI) database [online]. Dostupno na http://databank.worldbank.org/data/source/world-development-indicators [3. veljače 2020.]. 